\title{
Doping and Surface Modification Enhance the Applicability of Nanostructured Fullerene-MWCNT Hybrid Draped LiNiO.1Mg0.1Co0.802 As High Efficient Cathode Material for Lithium-Ion Batteries
}

\section{Arockia Shyamala Paniyarasi S}

No affiliation provided

Suja S K

No affiliation provided

Nimma Elizabeth R ( $\nabla$ nimmaelizabethldc@gmail.com )

Lady Doak College https://orcid.org/0000-0002-9759-994X

\section{Research Article}

Keywords: Lithium-ion, a layered cathode, Mg, Fullerene -MWCNT hybrid, charge transfer resistance, diffusion coefficient.

Posted Date: March 18th, 2021

DOl: https://doi.org/10.21203/rs.3.rs-306696/v1

License: (c) (1) This work is licensed under a Creative Commons Attribution 4.0 International License.

Read Full License 


\section{ABSTRACT}

Development of high performance cathode materials, layer-structured ternary $\mathrm{LiNi}_{\mathrm{x}} \mathrm{Co}_{\mathrm{y}} \mathrm{M}_{1-\mathrm{x}-\mathrm{y}} \mathrm{O}_{2}$ cathode materials have attracted much attention owing to their larger capacity and higher energy density.Persistent efforts have been devoted to tackling certain issues like low electronic conductivity and poor structural stability. Dual strategy of $\mathrm{Mg}$ doping and surface modification of the cathode material was adopted to improve the performance of the battery. Fullerene-Multi-Walled Carbon Nanotube (MWCNT) hybrid draped $\mathrm{LiNi}_{0.1} \mathrm{Mg}_{0.1} \mathrm{Co}_{0.8} \mathrm{O}_{2}$ nanocomposite was synthesized by a simple chemical route. The fullerene-MWCNT hybrid modifies the surface of pristine $\mathrm{LiNi}_{0.1} \mathrm{Mg}_{0.1} \mathrm{Co}_{0.8} \mathrm{O}_{2}$ thereby improves the electrochemical performance and maintains the structural stability of the cathode material. Pristine $\mathrm{LiNi}_{0.1} \mathrm{Mg}_{0.1} \mathrm{Co}_{0.8} \mathrm{O}_{2}$ and $\mathrm{LiNi}_{0.1} \mathrm{Mg}_{0.1} \mathrm{Co}_{0.8} \mathrm{O}_{2}$ /fullerene-MWCNT nanocomposite were studied using various advanced characterization techniques such as $\mathrm{X}$ ray diffraction (XRD), Micro-Raman spectroscopy, Field Emission Scanning Electron Microscopy (FESEM), X-ray Photoelectron Spectroscopy (XPS), and High-Resolution Transmission Electron Microscopy (HRTEM). It is found that $\mathrm{LiNi}_{0.1} \mathrm{Mg}_{0.1} \mathrm{Co}_{0.8} \mathrm{O}_{2}$ particles retain their structural integrity after being enveloped with a fullerene-MWCNT hybrid. The electrochemical performance was investigated with cyclic voltammetry $(\mathrm{CV})$, galvanostatic charge-discharge(GCD) test and electrochemical impedance spectroscopy(EIS). As prepared $\mathrm{LiNi}_{0.1} \mathrm{Mg}_{0.1} \mathrm{Co}_{0.8} \mathrm{O}_{2}$, when deployed in the form of $\mathrm{LiNi}_{0.1} \mathrm{Mg}_{0.1} \mathrm{Co}_{0.8} \mathrm{O}_{2} /$ fullerene-MWCNT composite exhibits a high specific capacity of $208 \mathrm{mAh} \mathrm{g}^{-1}$. Fullerene-MWCNT hybrid draped $\mathrm{LiNi}_{0.1} \mathrm{Mg}_{0.1} \mathrm{Co}_{0.8} \mathrm{O}_{2}$ nanocomposite provides an effective $\mathrm{Li}^{+}$and electron channel that significantly increased the Li-ion diffusion coefficient and reduced the charge transfer resistance. Besides, the lithium diffusion coefficient increased from $5.13 \times 10^{-13}$ 
$\left(\mathrm{Li} / \mathrm{LiNi}_{0.1} \mathrm{Mg}_{0.1} \mathrm{Co}_{0.8} \mathrm{O}_{2}\right)$ to $8.313 \times 10^{-13} \mathrm{~cm}^{2} \mathrm{~s}^{-1}$ due to the improved kinetics of $\mathrm{Li}$ insertion/extraction process in $\mathrm{Li} / \mathrm{LiNi}_{0.1} \mathrm{Mg}_{0.1} \mathrm{Co}_{0.8} \mathrm{O}_{2}+$ fullerene-MWCNT cell.

Keywords: Lithium-ion; a layered cathode; Mg; Fullerene -MWCNT hybrid; charge transfer resistance; diffusion coefficient.

\section{Introduction}

Lithium-ion batteries (LIBs) with transitional metal oxide as cathode materials recently play a significant role in energy storage systems for portable electronic devices[1]. There havebeen several investigations into ground-breaking novel nano-architectures to enhance the efficiency and lifetime of the LIB[2]. Various carbonaceous materials have been tested as electrodes for battery applications. However, to improve the electrochemical performance of layered cathode material, two strategies were often employed (i) partially replacing foreign atoms, such as $\mathrm{Cr}, \mathrm{Mg}, \mathrm{Al}$, and $\mathrm{F}$, in an attempt to improve structural stability and (ii) surface coating with a thin layer of metal oxide to suppress the lateral effects. In general, the incorporation of carbonaceous materials into transition metal oxide cathode materials to form a conductive network has become a favorable strategy for achieving better cycling performance and rate capability[3]. Owing to their unique physicochemical properties, the nanocarbon materials with different geometrical orientations (e.g., graphene, carbon nanotubes (CNTs), and fullerenes) have gained a lot of applicationsin lithium-ion batteries as the carbon materials provide enough space for storing lithium ions. The excellent conductivity of the nanocarbon material provides excellent lithium storage capacities and rate performances.

Carbon nanotubes are carbon allotropes with a cylindrical shape at the nanoscale level[4]. The structural, electrical, mechanical, and magnetic properties of CNTs, made it 
a possible candidate for industrial and large-scale applications[4,5]. Exceedingly, CNTs have been employed as conductive nanostructured carbon matrices to boost the specific power, rate capability, and cycling stability of the cathode materials[3]. Other important features that make doped CNTs to be used in lithium-ion batteries are high chemical resistance and low flammability[2]. The electrochemically reversible penetration of Li-ions in SWCNTs andMWCNTs has been extensively studied. Lithium ions diffuse to stable sites on either the outer or the inner surface of a single layer of CNT graphene.

Among various strategies, the bandgap approach has led several research groups, and in particular, Wonsang Koh et al.[6] reported that the new hybridized SWCNT/C 60 improves the passage of electrons to particle boundaries. Carbon-based materials are promising candidates for constructing 3D conductive networks, which boost active material utilization at high rates during the electrochemical reaction through electrical and ionic pathways[7]. Moreover, as reported in the literaturethe $\mathrm{Li}_{2} \mathrm{Mn}_{2.9} \mathrm{Ni}_{0.9} \mathrm{Co}_{0.2} \mathrm{O}_{8}-\mathrm{MWCNT}$ exhibited remarkable interesting properties such as high specific capacity, sufficient rate performance, significant Coulombic efficiency, and improved cycling stability compared with pristine $\mathrm{LiNi}_{0.1} \mathrm{Mg}_{0.1} \mathrm{Co}_{0.8} \mathrm{O}_{2}[8]$.

Our work broadens the scope of cathodic materials based on $\mathrm{LiNi}_{0.1} \mathrm{Mg}_{0.1} \mathrm{Co}_{0.8} \mathrm{O}_{2}$. In fact, Zhang et al.[9] have shown that the layered cathodic material like $\mathrm{LiNi}_{0.65} \mathrm{Mg}_{0.05} \mathrm{Co}_{0.3} \mathrm{O}_{2}$, synthesized by the sol-gel method delivered an initial discharge capacity of $178 \mathrm{mAh} \mathrm{g}^{-1}$ due to fewer cations mixtures. Xiang et al.[10] stated that the $\mathrm{Mg}$-doped $\mathrm{LiNi}_{0.8} \mathrm{Co}_{0.2} \mathrm{O}_{2}$ electrode delivered an initial discharge capacity of $188 \mathrm{mAh} \mathrm{g}^{-1}$ and retained good cycling behavior. Cho et al.[11] suggested that the $\mathrm{LiNi}_{0.74} \mathrm{Co}_{0.2} \mathrm{Mg}_{0.06} \mathrm{O}_{2}$ electrodes delivered a discharge capacity of $158 \mathrm{mAh} \mathrm{g}^{-1}$ with improved thermal stability. Therefore, the electrochemically inactive doping element $\mathrm{Mg}$ in $\mathrm{LiNi}_{\mathrm{x}} \mathrm{Co}_{\mathrm{y}} \mathrm{O}_{2}$ elevates the capacity of the cathodic material and retains high structural stability. The stability of cathode materials is 
enhanced by the promotion of lithium-ion transport due to the increased lithium slab gap by the $\mathrm{Mg}$ effect [12]. In addition, $\mathrm{Mg}^{2+}$ ions migrate to the interslab sites that were originally occupied by lithium ions, act as pillars, and sustain the delithiation structures, suppressing the cationic migration[13]. Many techniques have been explored to maintain the surface integrity of the cathode material, in which surface alteration is one of the simplest and most realistic methods that can effectively overwhelm the growth of solid electrolyte interphase level.

In this study, to explore the constructive outcomes such as improved cycling and electrochemical performance of the cathode material, $\mathrm{LiNi}_{0.1} \mathrm{Mg}_{0.1} \mathrm{Co}_{0.8} \mathrm{O}_{2}$ cathode material was synthesized by self-sustaining combustion route and $\mathrm{LiNi}_{0.1} \mathrm{Mg}_{0.1} \mathrm{Co}_{0.8} \mathrm{O}_{2}$ /fullereneMWCNT nanocomposite was synthesized by a simple chemical route. The novelty of the work lies in the addition of nickel to a very small percentage of the composite cathode, with $\mathrm{Mg}$ as a dopant, and the incorporation of fullerene-MWCNT hybrid into the layered cathode material. The partial substitution of cobalt with magnesium had a positive effect, minimized cation mixing, and favored the formation of layered cathode structures.

To the best of our knowledge, the influence of fullerene - MWCNT hybrid modification on the characteristics of the $\mathrm{LiNi}_{0.1} \mathrm{Mg}_{0.1} \mathrm{Co}_{0.8} \mathrm{O}_{2}$ with a very low content of nickel has not been reported yet. In this regard, the current piece of work assumes significant importance, as one of the early works demonstrates that for the first time the suitability of the fullerene-MWCNT hybrid draped $\mathrm{LiNi}_{0.1} \mathrm{Mg}_{0.1} \mathrm{Co}_{0.8} \mathrm{O}_{2}$ particles to construct a $3 \mathrm{D}$ conductive network.

The structural and electrochemical behavior studies of $\mathrm{LiNi}_{0.1} \mathrm{Mg}_{0.1} \mathrm{Co}_{0.8} \mathrm{O}_{2}$ and fullerene-MWCNT hybrid draped $\mathrm{LiNi}_{0.1} \mathrm{Mg}_{0.1} \mathrm{Co}_{0.8} \mathrm{O}_{2}$ nanocomposite were investigated and discussed in detail. In this work, the beneficial aspects of fullerene-MWCNT as a conductive 
additive in $\mathrm{LiNi}_{0.1} \mathrm{Mg}_{0.1} \mathrm{Co}_{0.8} \mathrm{O}_{2}$ and the synergy between $\mathrm{LiNi}_{0.1} \mathrm{Mg}_{0.1} \mathrm{Co}_{0.8} \mathrm{O}_{2}$ and fullerene -MWCNT hybrid materials are explored for their enhanced electrochemical properties.

\section{EXPERIMENTAL}

\subsection{Preparation of $\mathrm{LiNi}_{0.1} \mathrm{Mg}_{0.1} \mathrm{Co}_{0.8} \mathrm{O}_{2}$ / fullerene-MWCNT nanocomposite}

Fullerene-MWCNT powder (ground core, 7-12nm OD, 0.5-10 micron long, Alfa Aesar) was used as a precursor. Fig.1 clearly explains the various processes involved in the fabrication of $\mathrm{LiNi}_{0.1} \mathrm{Mg}_{0.1} \mathrm{Co}_{0.8} \mathrm{O}_{2}$ / fullerene-MWCNT nanocomposite cathode material. Initially, $0.025 \mathrm{~g}$ of fullerene-MWCNT and $0.5 \mathrm{~g}$ of $\mathrm{LiNi}_{0.1} \mathrm{Mg}_{0.1} \mathrm{Co}_{0.8} \mathrm{O}_{2}$ nanopowder were ground for 30 minutes in a mortar with a pestle. The blend was dispersed by ultra-sonication with $15 \mathrm{ml}$ of ethanol. The solution was vigorously stirred for 4 hours at $50^{\circ} \mathrm{C}$. Finally, the resultant mixture was dried overnight in an oven at $80^{\circ} \mathrm{C}$ to obtain the fullerene- MWCNT hybrid draped $\mathrm{LiNi}_{0.1} \mathrm{Mg}_{0.1} \mathrm{Co}_{0.8} \mathrm{O}_{2}$ nanocomposite as reported earlier by Jan et al[3]. 


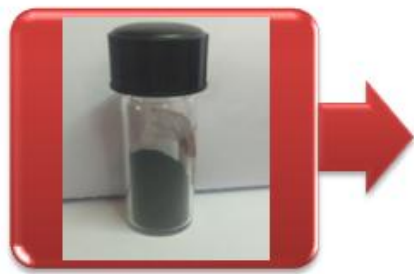

Active material

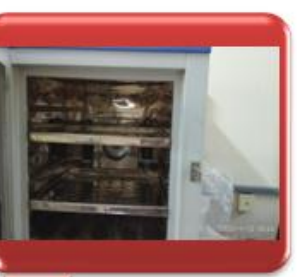

Dried at $80^{\circ} \mathrm{C}$

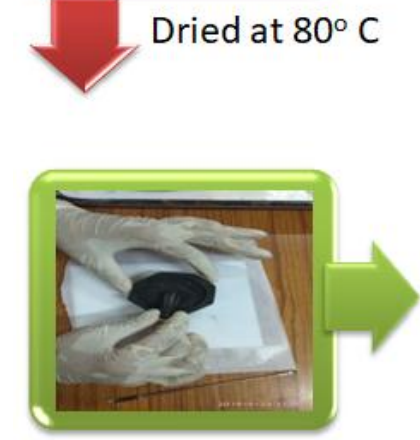

Slurry

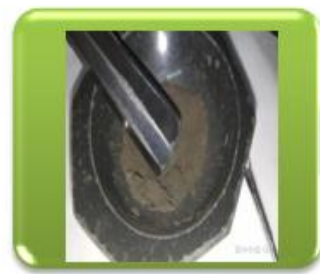

Mixture of active material + fullerene -

MWCNT

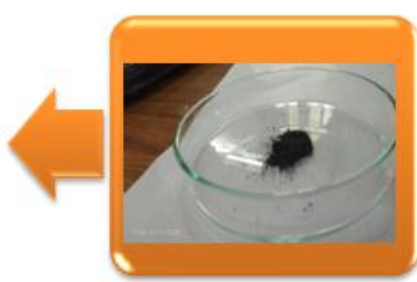

Nanocomposite cathode material

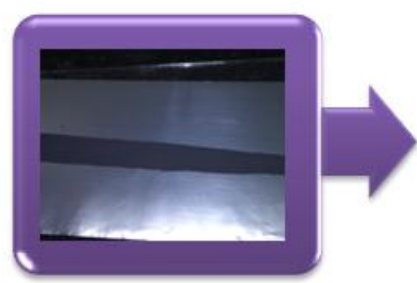

Coating

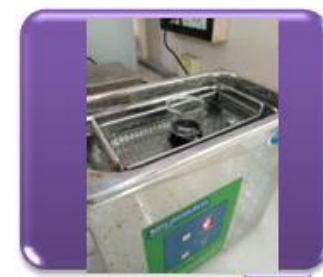

Ultra-sonication

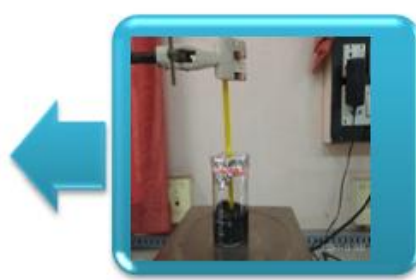

Vigorous stirring at $50^{\circ} \mathrm{C}$

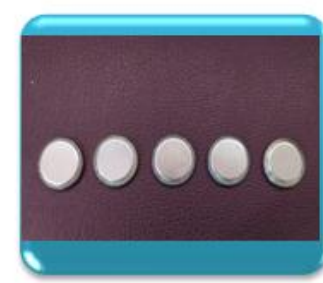

Coin cells

Fig.1 The schematic diagram of the process involved in the preparation of the $\mathrm{LiNi}_{0.1} \mathrm{Mg}_{0.1} \mathrm{Co}_{0.8} \mathrm{O}_{2}$ / fullerene-MWCNT nanocomposite and its coin cells

\subsection{Instruments used for structural characterization}

The structural properties were studied by X-ray diffractometer (XRD, Shimadzu XRD- 6000) and the morphological properties of as-prepared samples were analyzed by field-emission scanning electron microscopy (FESEM, JSM-6700F $15 \mathrm{kV}$ ), and highresolution transmission electron microscopy (HRTEM, JEOL 2010200 kV). Micro-Raman scattering measurements were conducted using a DXR Raman Microscope (Thermo Fisher Scientific Inc.) and the source of excitation used was an argon-ion laser operating at $514 \mathrm{~nm}$ with a laser incident power of $0.3 \mathrm{~mW}$. For quantitative chemical insights, the as-synthesized particles were characterized by X-ray photoelectron spectroscopy (XPS). 


\subsection{Fabrication of electrode and electrochemical measurements}

The synthesized $\mathrm{LiNi}_{0.1} \mathrm{Mg}_{0.1} \mathrm{Co}_{0.8} \mathrm{O}_{2}$ / fullerene-MWCNT composite material, acetylene black and polyvinylidene fluoride (PVDF) in the proportion of 80:10:10 in NMethyl-2-Pyrrolidone (NMP) were added together and mixed thoroughly to obtain the slurry. The slurry was carefully coated onto an aluminium foil by the doctor-blade technique and dried at $70^{\circ} \mathrm{C}$ to remove water content. The 2032-type coin cells with the coated material as cathode, lithium metal as an anode, and Celgard 2325 membrane as the separator were assembled. In a similar way, the 2032-type coin cells with $\mathrm{LiNi}_{0.1} \mathrm{Mg}_{0.1} \mathrm{Co}_{0.8} \mathrm{O}_{2}$ coated material as the cathode, lithium metal as an anode, and Celgard 2325 membrane as the separator were also assembled. The separator was wetted with the electrolyte $1 \mathrm{M} \mathrm{LiPF}_{6}$ inEC:DEC;1:1(v/v).

Between a potential window $2.5-4.5 \mathrm{~V}$, the cycling profile for the prepared coin cells was studied at room temperature. The voltammograms were analyzed using the SP150 (Biologic) electrochemical impedance analyzer at $0.1 \mathrm{mVs}^{-1}$. Electrochemical Impedance Spectroscopy (EIS) for coin cells was recorded between $200 \mathrm{kHz}$ to $100 \mathrm{mHz}$ frequency.

\section{Results and Discussion}

\subsection{XRD analysis}

Fig. 2 shows the XRD pattern of $\mathrm{LiNi}_{0.1} \mathrm{Mg}_{0.1} \mathrm{Co}_{0.8} \mathrm{O}_{2}$, fullerene-MWCNT hybrid draped $\mathrm{LiNi}_{0.1} \mathrm{Mg}_{0.1} \mathrm{Co}_{0.8} \mathrm{O}_{2}$, and fullerene-MWCNT hybrid. From Fig. 2(a\&b), the $R 3 m$ space group related patterns of $\mathrm{LiNi}_{0.1} \mathrm{Mg}_{0.1} \mathrm{Co}_{0.8} \mathrm{O}_{2}$ and fullerene-MWCNT hybrid draped $\mathrm{LiNi}_{0.1} \mathrm{Mg}_{0.1} \mathrm{Co}_{0.8} \mathrm{O}_{2}$ nanocomposite were confirmed by the existence of diffraction peak at $2 \theta$ $=38^{\circ}$ and $46^{\circ}$. A well-layered nanostructure was observed from the distinct splitting of 006/102 and 108/110 doublet peaks[14] 


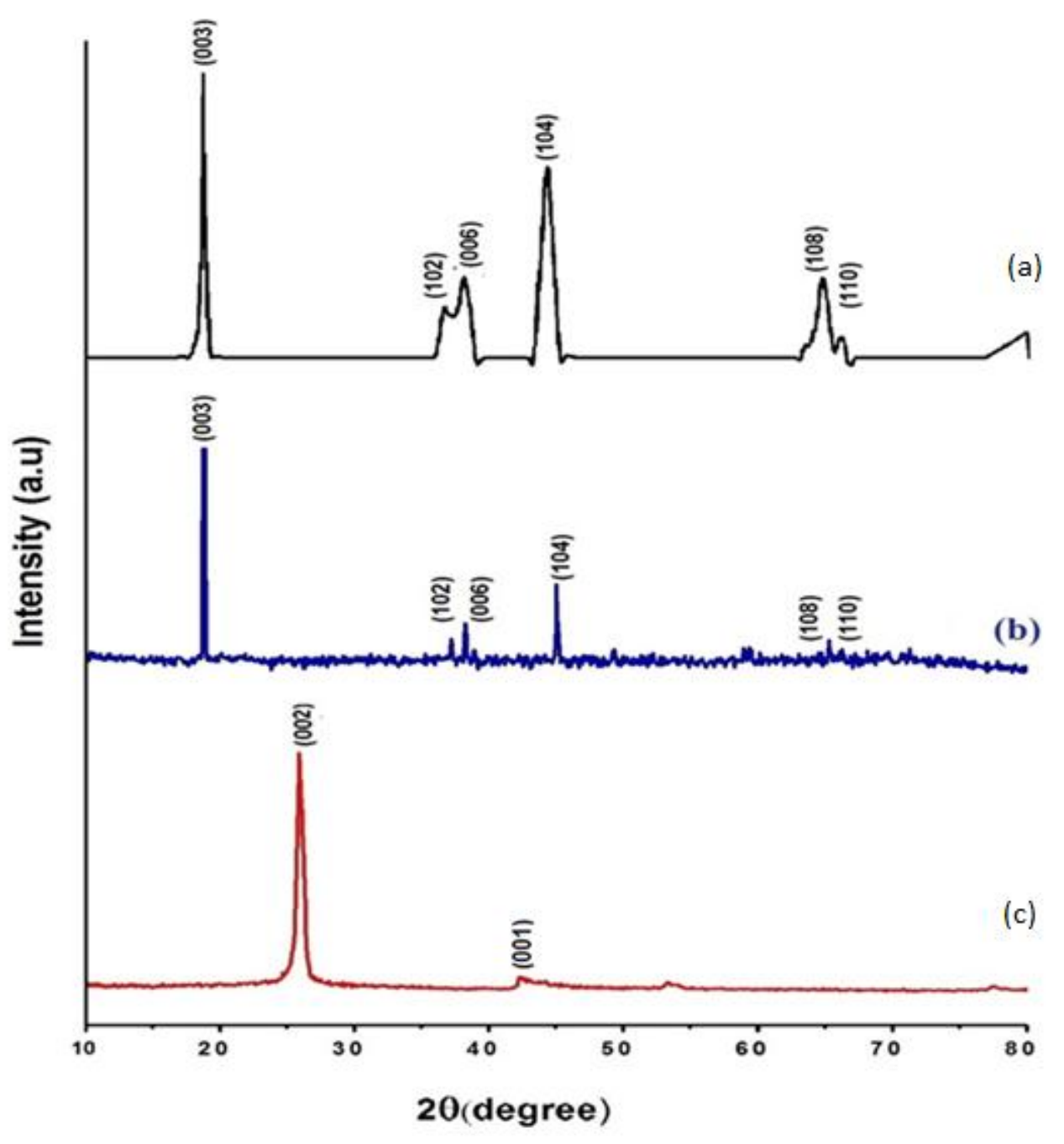

Fig. 2 XRD pattern of (a) $\mathrm{LiNi}_{0.1} \mathrm{Mg}_{0.1} \mathrm{Co}_{0.8} \mathrm{O}_{2}$ (b) fullerene-MWCNT hybrid draped $\mathrm{LiNi}_{0.1} \mathrm{Mg}_{0.1} \mathrm{Co}_{0.8} \mathrm{O}_{2}$ and (c) fullerene-MWCNT hybrid

The XRD pattern of the fullerene-MWCNT hybrid, shown in Fig. 2(c) which displayed two peaks located at $2 \theta=25.74^{\circ} \& 42.87^{\circ}$ can be ascribed to the hexagonal graphite crystal planes of (002) and (001) respectively.Also, the XRD pattern of fullerene-MWCNT hybrid draped $\mathrm{LiNi}_{0.1} \mathrm{Mg}_{0.1} \mathrm{Co}_{0.8} \mathrm{O}_{2}$ nanocomposite does not reveal the diffraction peaks of graphene or graphite is likely due to the extremely crystalline phase of $\mathrm{LiNi}_{0.1} \mathrm{Mg}_{0.1} \mathrm{Co}_{0.8} \mathrm{O}_{2}$ nanocomposite[5].

The lattice constants (a \& c) for $\mathrm{LiNi}_{0.1} \mathrm{Mg}_{0.1} \mathrm{Co}_{0.8} \mathrm{O}_{2}$ and fullerene-MWCNT hybrid draped $\mathrm{LiNi}_{0.1} \mathrm{Mg}_{0.1} \mathrm{Co}_{0.8} \mathrm{O}_{2}$ nanocompositewere $2.871 \AA$ А $; 14.196 \AA$ and $2.859 \AA ; 14.156 \AA$ 
respectively. The c/a ratio of the pristine and fullerene-MWCNThybrid draped $\mathrm{LiNi}_{0.1} \mathrm{Mg}_{0.1} \mathrm{Co}_{0.8} \mathrm{O}_{2}$ nanocomposite was found to be higher than the 4.9. Also, the ratio of $\mathrm{I}_{003} / \mathrm{I}_{104}$ for the pristine and fullerene-MWCNT hybrid draped $\mathrm{LiNi}_{0.1} \mathrm{Mg}_{0.1} \mathrm{Co}_{0.8} \mathrm{O}_{2}$ composite is greater than 1.2 indicating the low $\left(\mathrm{Li}^{+}\right.$and $\left.\mathrm{Ni}^{2+}\right)$ cation mixing[9].

The physical mixing of fullerene-MWCNT hybrid in $\mathrm{LiNi}_{0.1} \mathrm{Mg}_{0.1} \mathrm{Co}_{0.8} \mathrm{O}_{2}$ has been reported to have an insignificant effect on the properties of MWCNTs relative to the covalent hybrid structure. The XRD results show that the surface modification with fullereneMWCNT hybrid does not affect the crystal structure and preserves the structural stability of the electrode component.

\subsection{FESEM Analysis}

The surface morphology patterns of pristine $\mathrm{LiNi}_{0.1} \mathrm{Mg}_{0.1} \mathrm{Co}_{0.8} \mathrm{O}_{2}$, fullerene-MWCNT hybrid, and fullerene-MWCNT hybrid draped $\mathrm{LiNi}_{0.1} \mathrm{Mg}_{0.1} \mathrm{Co}_{0.8} \mathrm{O}_{2}$ nanocomposite electrode were examined by FESEM as shown in Fig. 3 respectively. Incidentally, Fig. 3(a) shows the formation of cubic shaped like nanoparticles of pristine $\mathrm{LiNi}_{0.1} \mathrm{Mg}_{0.1} \mathrm{Co}_{0.8} \mathrm{O}_{2}$ which is also confirmed from the high-resolution TEM images as shown in Fig.5(a). The FESEM images as shown in Fig. 3(b) of fullerene-MWCNT hybrid show small spherical shaped like fullerene nanoparticles with an average particle size of $22 \mathrm{~nm}$ and MWCNT length of $1.06 \mu \mathrm{m}$ as shown in histograms of particle size and MWCNT length distribution in Fig.3(c\&d). The wellconnected MWCNT conductive networks adhered to the surface nanocluster particles improved the electrochemical recombination effect of the cathodic ions[15]. 


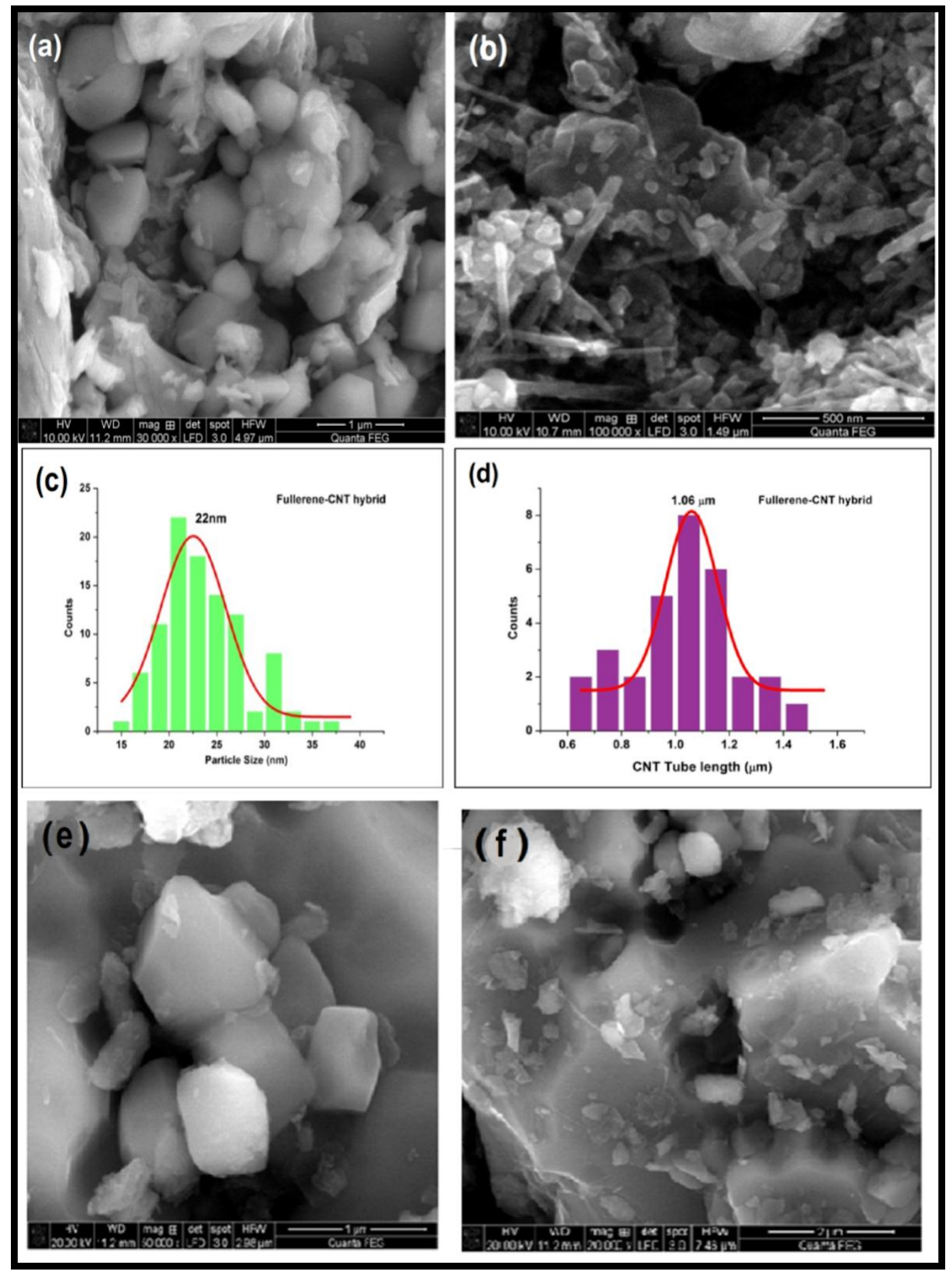

Fig.3 FESEM images of (a) $\mathrm{LiNi}_{0.1} \mathrm{Mg}_{0.1} \mathrm{Co}_{0.8} \mathrm{O}_{2}$ (b) fullerene-MWCNT hybrid (c) Histogram of the particle size distribution in fullerene- MWCNT hybrid (d) Histogram of the MWCNT length distribution in fullerene-MWCNT hybrid (e) and (f) fullereneMWCNT hybrid draped $\mathrm{LiNi}_{0.1} \mathrm{Mg}_{0.1} \mathrm{Co}_{0.8} \mathrm{O}_{2}$ at different dimensions

Fig. 3(e\&f) shows the FESEM images of fullerene-MWCNT hybrid draped $\mathrm{LiNi}_{0.1} \mathrm{Mg}_{0.1} \mathrm{Co}_{0.8} \mathrm{O}_{2}$ at different dimensions. The $\mathrm{LiNi}_{0.1} \mathrm{Mg}_{0.1} \mathrm{Co}_{0.8} \mathrm{O}_{2}$ nanocubes found in clusters were separated by the presence of fullerene and MWCNTs (Fig.3e). The 
$\mathrm{LiNi}_{0.1} \mathrm{Mg}_{0.1} \mathrm{Co}_{0.8} \mathrm{O}_{2}$ nanocubes accommodated into the holes of fullerenes are further wrapped by MWCNT as shown in Fig. 3(f).

\subsection{FTIR Analysis}

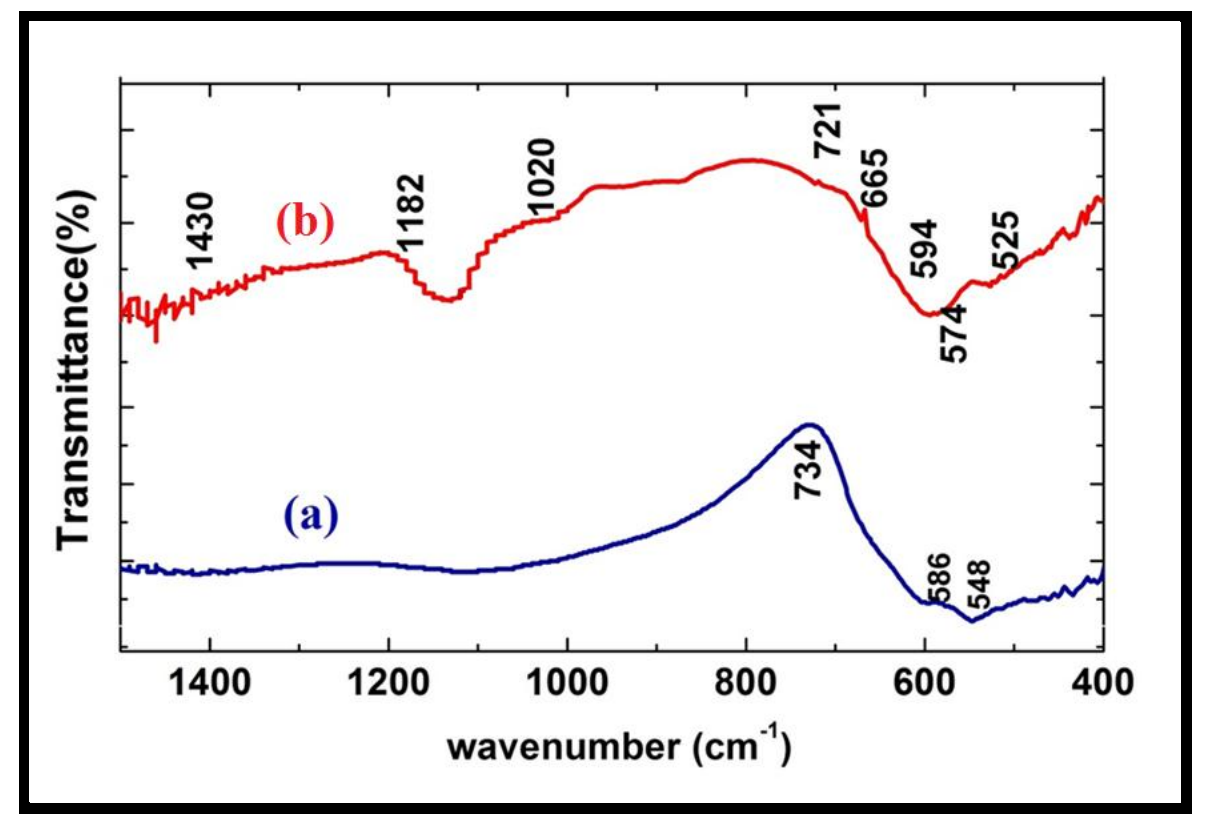

Fig. 4 FTIR spectrum of (a) pristine $\mathrm{LiNi}_{0.1} \mathrm{Mg}_{0.1} \mathrm{Co}_{0.8} \mathrm{O}_{2}$ and (b) fullerene-MWCNT hybrid draped $\mathrm{LiNi}_{0.1} \mathrm{Mg}_{0.1} \mathrm{Co}_{0.8} \mathrm{O}_{2}$ nanocomposite

The formation of $\mathrm{LiNi}_{0.1} \mathrm{Mg}_{0.1} \mathrm{Co}_{0.8} \mathrm{O}_{2}$ and fullerene-MWCNT hybrid draped $\mathrm{LiNi}_{0.1} \mathrm{Mg}_{0.1} \mathrm{Co}_{0.8} \mathrm{O}_{2}$ was further confirmed by FT-IR analysis. Fig. 4(a) shows the mode of vibrations of synthesized pristine layered nanostructure of $\mathrm{LiNi}_{0.1} \mathrm{Mg}_{0.1} \mathrm{Co}_{0.8} \mathrm{O}_{2}$ cathode material in the region between $500-1400 \mathrm{~cm}^{-1}$. The observed peaks at 548,586 and $734 \mathrm{~cm}^{-1}$ represent the stretching modes of $\mathrm{MO}_{6}[16]$. The peak at $548 \mathrm{~cm}^{-1}$ elucidates the asymmetric elongation of $\mathrm{MO}$ bonds in the vicinity of $\mathrm{MO}_{6}$ octahedral[17]. In the spectrum (Fig.4b) of fullerene-MWCNT hybrid draped $\mathrm{LiNi}_{0.1} \mathrm{Mg}_{0.1} \mathrm{Co}_{0.8} \mathrm{O}_{2}$, the peaks at 594, 665and $721 \mathrm{~cm}^{-1}$ indicate the stretching modes of $\mathrm{MO}_{6}$ of $\mathrm{LiNi}_{0.1} \mathrm{Mg}_{0.1} \mathrm{Co}_{0.8} \mathrm{O}_{2}$. Besides, the peaks at 525, 574, 1182 , and $1430 \mathrm{~cm}^{-1}$ confirm the $\mathrm{F}_{1 \mathrm{u}}$ mode of active vibrations of the fullerene regime. The peak around $1020 \mathrm{~cm}^{-1}$ was assigned to the vibration of the $\mathrm{C}-\mathrm{O}$ of the MWCNT[18]. The 
FTIR analysis confirms the presence of fullerene-MWCNT hybrid in the synthesized composite of cathode material.

\subsection{HRTEM Analysis}

The microstructure of $\mathrm{LiNi}_{0.1} \mathrm{Mg}_{0.1} \mathrm{Co}_{0.8} \mathrm{O}_{2}$ and $\mathrm{LiNi}_{0.1} \mathrm{Mg}_{0.1} \mathrm{Co}_{0.8} \mathrm{O}_{2}$ / fullereneMWCNT hybrid nanocomposite were investigated by high-resolution TEM (HRTEM). Fig. 5(a) shows that pristine $\mathrm{LiNi}_{0.1} \mathrm{Mg}_{0.1} \mathrm{Co}_{0.8} \mathrm{O}_{2}$ presented a nanocube like structure arranged one over the other. Fig. 5(b) represents the HRTEM image of fullerene-MWCNT hybrid draped $\mathrm{LiNi}_{0.1} \mathrm{Mg}_{0.1} \mathrm{Co}_{0.8} \mathrm{O}_{2} \quad$ nanocomposite which shows that individual $\mathrm{LiNi}_{0.1} \mathrm{Mg}_{0.1} \mathrm{Co}_{0.8} \mathrm{O}_{2}$ nanocubes are well dispersed, bonded with the spherical fullerenes, and enveloped by the transparent backbones of MWCNTs. The $\mathrm{LiNi}_{0.1} \mathrm{Mg}_{0.1} \mathrm{Co}_{0.8} \mathrm{O}_{2}$ particles were separated by the multi-walled carbon nanotubes and thereby agglomeration of $\mathrm{LiNi}_{0.1} \mathrm{Mg}_{0.1} \mathrm{Co}_{0.8} \mathrm{O}_{2}$ particles was barred. During the composite formation, MWCNTs were broken and they infringeinto the particles of $\mathrm{LiNi}_{0.1} \mathrm{Mg}_{0.1} \mathrm{Co}_{0.8} \mathrm{O}_{2}$. The broken ends of the nanotubes are extruded but not totally isolated from the composites of $\mathrm{LiNi}_{0.1} \mathrm{Mg}_{0.1} \mathrm{Co}_{0.8} \mathrm{O}_{2}$ and are still connected with the composites.

Such findings confirm that the MWCNTs are well embedded into the fullereneMWCNT hybrid draped $\mathrm{LiNi}_{0.1} \mathrm{Mg}_{0.1} \mathrm{Co}_{0.8} \mathrm{O}_{2}$ nanocomposite. In addition, the micro-Raman shows that the composite forms a dense covering layer showing defects on the walls and edges of the carbon nanotubes[19].

Fig. 5(c \& d) shows histogram plots of length and diameter distribution of fullereneMWCNT hybrid draped $\mathrm{LiNi}_{0.1} \mathrm{Mg}_{0.1} \mathrm{Co}_{0.8} \mathrm{O}_{2}$ nanocomposite. 


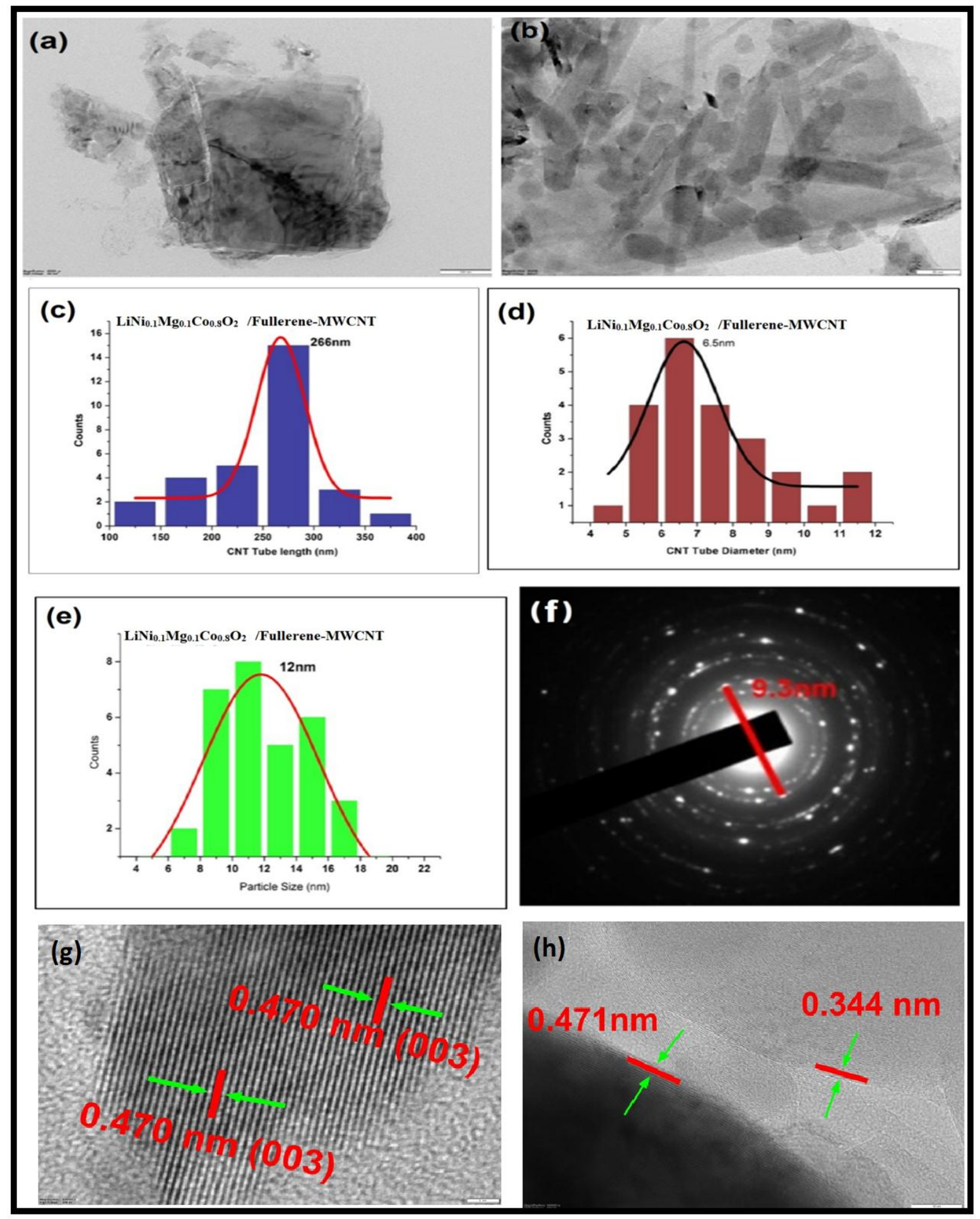

Fig.5 HRTEM images of (a) $\mathrm{LiNi}_{0.1} \mathrm{Mg}_{0.1} \mathrm{Co}_{0.8} \mathrm{O}_{2}$ (b) Fullerene- MWCNT hybrid $\begin{array}{lll}\text { draped } & \mathrm{LiNi}_{0.1} \mathrm{Mg}_{0.1} \mathrm{Co}_{0.8} \mathrm{O}_{2} & \text { (c) \&(d) Histogram of }\end{array}$ MWCNT length and diameter distribution in fullerene- MWCNT hybrid draped $\mathrm{LiNi}_{0.1} \mathrm{Mg}_{0.1} \mathrm{Co}_{0.8} \mathrm{O}_{2}$ (e) Histogram of the particle size distribution in the composite and (f) SAED of fullerene- MWCNT hybrid draped $\mathrm{LiNi}_{0.1} \mathrm{Mg}_{0.1} \mathrm{Co}_{0.8} \mathrm{O}_{2}$ (g) and (h) Lattice fringes of $\mathrm{LiNi}_{0.1} \mathrm{Mg}_{0.1} \mathrm{Co}_{0.8} \mathrm{O}_{2}$ and fullereneMWCNT hybrid draped $\mathrm{LiNi}_{0.1} \mathrm{Mg}_{0.1} \mathrm{Co}_{0.8} \mathrm{O}_{2}$ 
From the histogram plots Fig. 5(c) it was noted that the MWCNTs have an average length of $266 \mathrm{~nm}$ with an average MWCNT diameter of $6.5 \mathrm{~nm}$ as shown in Fig.5(d) in the composite. The histogram plot in Fig. 5(e) had recorded an average particle size of $12 \mathrm{~nm}$.

The well-defined diffraction spots from the selected area electron diffraction pattern (SAED) as shown in Fig.5(f) confirm the crystalline nature of fullerene- MWCNT hybrid draped $\mathrm{LiNi}_{0.1} \mathrm{Mg}_{0.1} \mathrm{Co}_{0.8} \mathrm{O}_{2}$ nanocomposite. From SAED, the observed interplanar spacing $d$ is about $0.465 \mathrm{~nm}$ for fullerene- MWCNT hybrid draped $\mathrm{LiNi}_{0.1} \mathrm{Mg}_{0.1} \mathrm{Co}_{0.8} \mathrm{O}_{2}$ nanocomposite which matches quite well with the $d$-spacing of (003) planes as reported in XRD section 3.1.

From the data, it can be argued that high-resolution transmission electron microscopy images of the pristine $\mathrm{LiNi}_{0.1} \mathrm{Mg}_{0.1} \mathrm{Co}_{0.8} \mathrm{O}_{2}$ nanoparticles, shown in Fig. 5(g) reveal the crystalline nature of the mixtures. The $d$-spacing of $\mathrm{LiNi}_{0.1} \mathrm{Mg}_{0.1} \mathrm{Co}_{0.8} \mathrm{O}_{2}$ nanoparticle $(0.471 \mathrm{~nm})$ obtained from the HRTEM image exactly matched with the most intense lines of (003) plane from the X-ray diffraction pattern as reported in section 3.1

The HRTEM image of fullerene- MWCNT hybrid draped $\mathrm{LiNi}_{0.1} \mathrm{Mg}_{0.1} \mathrm{Co}_{0.8} \mathrm{O}_{2}$ nanocomposite shown in Fig. 5(h) discloses well-defined lattice fringes with a separation of $0.471 \mathrm{~nm}$ corresponding to (003) plane of $\mathrm{LiNi}_{0.1} \mathrm{Mg}_{0.1} \mathrm{Co}_{0.8} \mathrm{O}_{2}$ and another separation of $0.344 \mathrm{~nm}$ corresponding to the graphitic crystalline planes of (002) respectively.

Minimizing the particle size to about $12 \mathrm{~nm}$ effectively decreases the length of the diffusion path of the charging species and favors high rate capability[20].

\subsection{Micro -Raman spectral Analysis}

Micro-Raman spectra of pristine $\mathrm{LiNi}_{0.1} \mathrm{Mg}_{0.1} \mathrm{Co}_{0.8} \mathrm{O}_{2}$, fullerene- MWCNT hybrid draped $\mathrm{LiNi}_{0.1} \mathrm{Mg}_{0.1} \mathrm{Co}_{0.8} \mathrm{O}_{2}$ and fullerene-MWCNT hybrid are shown in Fig. 6. According to the theoretical factor-group study, there are two Raman active modes of $E_{g}$ and $A_{1 g}$ for the 
layered metal oxides with the $R 3 m$ as a space group[21]. The $\mathrm{LiNi}_{0.1} \mathrm{Mg}_{0.1} \mathrm{Co}_{0.8} \mathrm{O}_{2}$ Raman spectrum (Fig. 6(a)) shows bands of $E_{g}$ and $A_{1 g}$ at $540.78 \mathrm{~cm}^{-1}$ and $649.63 \mathrm{~cm}^{-1}$.

In the Raman spectrum of the fullerene-MWCNT hybrid draped $\mathrm{LiNi}_{0.1} \mathrm{Mg}_{0.1} \mathrm{Co}_{0.8} \mathrm{O}_{2}$ composite shown in Fig.6(b), aside from the two Raman bands assigned to the pristine $\mathrm{LiNi}_{0.1} \mathrm{Mg}_{0.1} \mathrm{Co}_{0.8} \mathrm{O}_{2}$, all the characteristic bands ofthe fullerene-MWCNT hybrid were retained without any shift. This shows the intercalative mode of interaction between pristine $\mathrm{LiNi}_{0.1} \mathrm{Mg}_{0.1} \mathrm{Co}_{0.8} \mathrm{O}_{2}$ powders and the hybrid.

Slight downshifts in the intensity of $\mathrm{E}_{\mathrm{g}}$ and $\mathrm{A}_{1 \mathrm{~g}}$ bands $\left(489.36 \mathrm{~cm}^{-1}\right.$ and $\left.587.44 \mathrm{~cm}^{-1}\right)$ were observed for the composite when compared to the bands of pristine $\mathrm{LiNi}_{0.1} \mathrm{Mgg}_{0.1} \mathrm{Co}_{0.8} \mathrm{O}_{2}$ in Fig. 6(a). This is due to the conformational changes that occurred within $\mathrm{LiNi}_{0.1} \mathrm{Mg}_{0.1} \mathrm{Co}_{0.8} \mathrm{O}_{2}$ during composite formation.

The Raman spectrum of fullerene-MWCNT hybrid as shown in Fig. 6(c) displayed a strong $\mathrm{G}$ band at $1574.33 \mathrm{~cm}^{-1}$ which arises from the tangential $\mathrm{C}-\mathrm{C}$ bond stretching with $\mathrm{sp}^{2}$ hybridized carbon atoms in an ordered graphitic structure and corresponds to a splitting of the $\mathrm{E}_{2 \mathrm{~g}}$ stretching mode of crystalline graphite. A weak D band at $1349.41 \mathrm{~cm}^{-1}$ arises due to the disorder-induced in $\mathrm{sp}^{2}$ - bonded carbon. The intensity of the D-band corresponds to the open-ended $\mathrm{sp}^{3}$ hybridized carbon atoms, associated with the measurement of disorders in the $\mathrm{C}-\mathrm{C}$ bonds[22]. A 2D band at $2696.51 \mathrm{~cm}^{-1}$ is the characteristic band of graphene. This observation again confirms the non-covalent interaction of $\mathrm{LiNi}_{0.1} \mathrm{Mg}_{0.1} \mathrm{Co}_{0.8} \mathrm{O}_{2}$ with fullereneMWCNT hybrid[22]. 


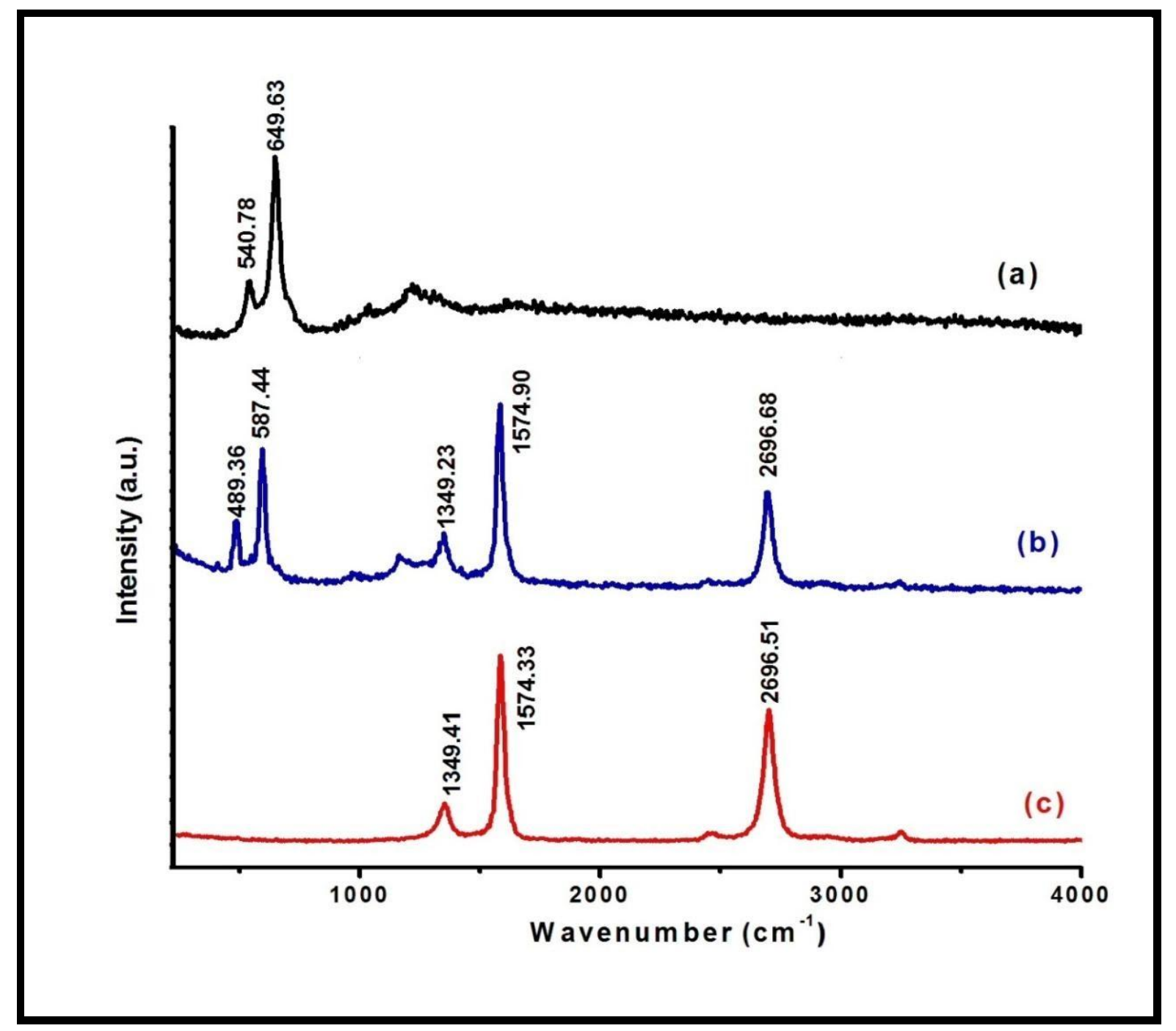

Fig. 6 Raman spectrum of (a) pristine $\mathrm{LiNi}_{0.1} \mathrm{Mg}_{0.1} \mathrm{Co}_{0.8} \mathrm{O}_{2 .}$ (b) fullerene- MWCNT hybrid draped $\mathrm{LiNi}_{0.1} \mathrm{Mg}_{0.1} \mathrm{Co}_{0.8} \mathrm{O}_{2}$, and (c) fullerene-MWCNT hybrid matrices

\subsection{X-Ray Photoelectron Spectra analysis}

To gain further insight into the oxidation state of metal elements in pristine $\mathrm{LiNi}_{0.1} \mathrm{Mg}_{0.1} \mathrm{Co}_{0.8} \mathrm{O}_{2}$ and fullerene- MWCNT hybrid draped $\mathrm{LiNi}_{0.1} \mathrm{Mg}_{0.1} \mathrm{Co}_{0.8} \mathrm{O}_{2}$, X-ray Photoelectron Spectroscopy (XPS) measurement was performed as shown in Fig.7. The Li 1s spectrum in Fig. 7(a) consists of two peaks at 68 and $59 \mathrm{eV}$ assigned to $\mathrm{Li}^{+}$ions of the lamellar oxide. The $\mathrm{O} 1 \mathrm{~s}$ spectrum as shown in Fig. 7(b) consists of two peaks at $531 \mathrm{eV}$ and 


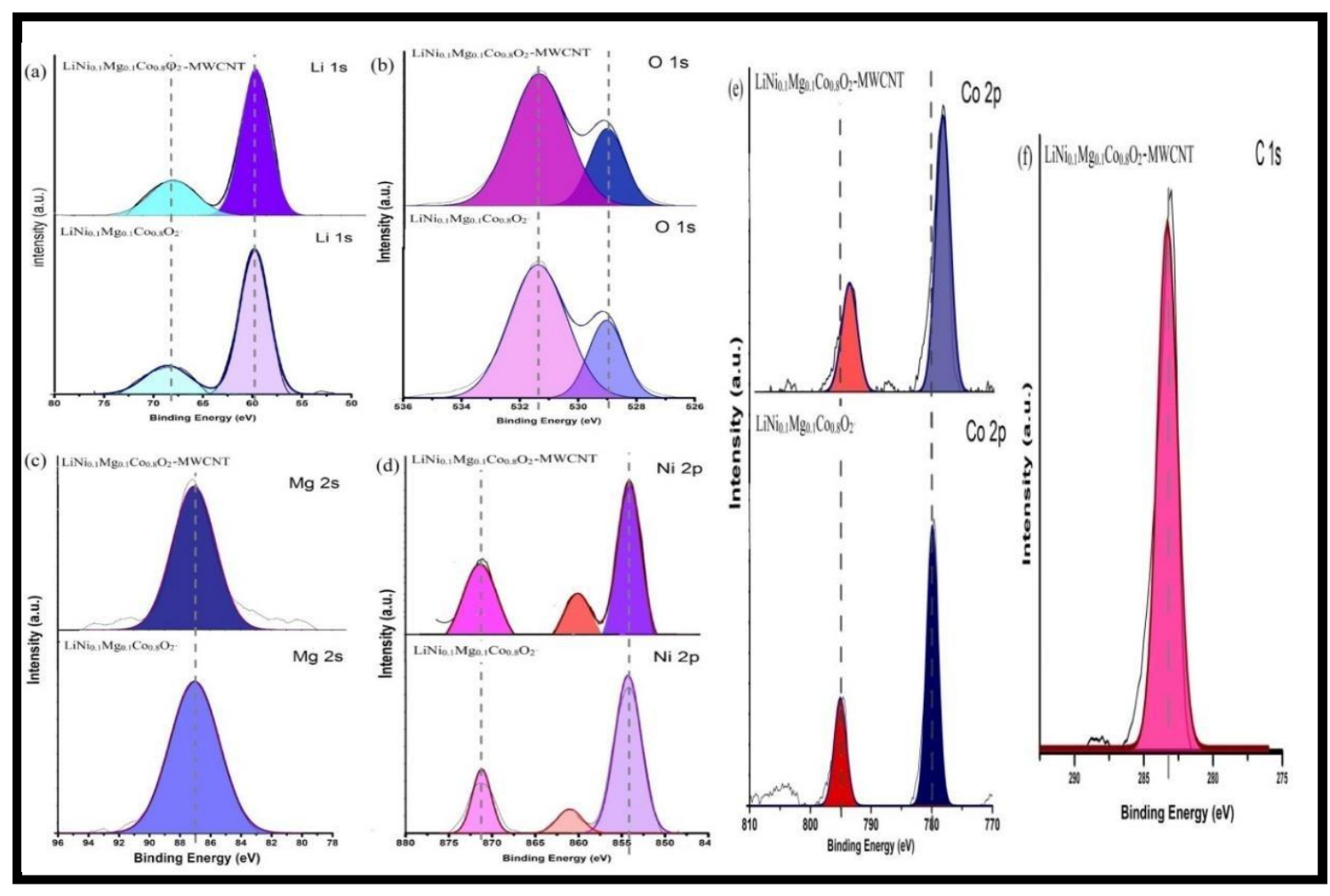

Fig. 7 XPS spectra (a) Li 1s (b) O 1s (c) Mg 2s (d) Ni 2p (e) Co 2p (f) C 1s of $\mathrm{LiNi}_{0.1} \mathrm{Mg}_{0.1} \mathrm{Co}_{0.8} \mathrm{O}_{2}$ and fullerene- MWCNT hybrid draped $\mathrm{LiNi}_{0.1} \mathrm{Mg}_{0.1} \mathrm{Co}_{0.8} \mathrm{O}_{2}$

another at $529 \mathrm{eV}$. The peak of the $\mathrm{Mg}$ 2s spectrum as shown in Fig. 7(c) is seen at $87 \mathrm{eV}$.The $\mathrm{Ni} 2 \mathrm{p}$ spectrum in Fig. 7(d) reveals two main core peaks of $\mathrm{Ni} 2 \mathrm{p}$ at $854 \mathrm{eV}\left(\mathrm{Ni} 2 \mathrm{p}^{3 / 2}\right)$ and $871 \mathrm{eV}\left(\mathrm{Ni} 2 \mathrm{p}^{1 / 2}\right)$ with an associated satellite peak at $861 \mathrm{eV}\left(\mathrm{Ni} 2 \mathrm{p}^{3 / 2}\right)[23]$. The Co $2 \mathrm{p}$ core peaks of $\mathrm{LiNi}_{0.1} \mathrm{Mg}_{0.1} \mathrm{Co}_{0.8} \mathrm{O}_{2}$ and $\mathrm{LiNi}_{0.1} \mathrm{Mg}_{0.1} \mathrm{Co}_{0.8} \mathrm{O}_{2}$ / fullerene-MWCNT composite are shown in Fig. 7(e). The spectrum splits into two parts $\left(\right.$ Co $2 \mathrm{p}^{3 / 2}$ and $\left.\operatorname{Co} 2 \mathrm{p}^{1 / 2}\right)$ due to spinorbit coupling, with an intensity ratio of $2: 1$. The main peak of Co $2 p^{3 / 2}$ for $\mathrm{LiNi}_{0.1} \mathrm{Mg}_{0.1} \mathrm{Co}_{0.8} \mathrm{O}_{2}$ and $\mathrm{LiNi}_{0.1} \mathrm{Mg}_{0.1} \mathrm{Co}_{0.8} \mathrm{O}_{2}$ / fullerene- doped MWCNT composite is positioned at 780 and $778 \mathrm{eV}$ respectively [23]. The Co $2 \mathrm{p}^{1 / 2}$ components are located at $795 \mathrm{eV}$ and $793 \mathrm{eV}$ for $\mathrm{LiNi}_{0.1} \mathrm{Mg}_{0.1} \mathrm{Co}_{0.8} \mathrm{O}_{2}$ and $\mathrm{LiNi}_{0.1} \mathrm{Mg}_{0.1} \mathrm{Co}_{0.8} \mathrm{O}_{2}$ / fullerene-MWCNT composite respectively.

The shift towards lower binding energy indicates the $\mathrm{Co}^{2+}$ oxidation state.The observed C 1s peak at $283 \mathrm{eV}$ in the $\mathrm{LiNi}_{0.1} \mathrm{Mg}_{0.1} \mathrm{Co}_{0.8} \mathrm{O}_{2} /$ fullerene-MWCNT composite in 
Fig. 7(f) mainly represents graphitic carbon[23]. As reported in the literature[24] the modification of NCM with grapheneoxide can lead to the transition metals changing their oxidation states and issue in low discharge capacity and poor cycling performance. In this work, the observed XPS peaks of fullerene- MWCNT hybrid draped $\mathrm{LiNi}_{0.1} \mathrm{Mg}_{0.1} \mathrm{Co}_{0.8} \mathrm{O}_{2}$ nanocompositeare almost identical with those of $\mathrm{LiNi}_{0.1} \mathrm{Mg}_{0.1} \mathrm{Co}_{0.8} \mathrm{O}_{2}$, which indicates that the incorporation of fullerene-MWCNT hybrid did not affect the oxidation state of the elements by which the cathode material maintains its structural stability. This is confirmed by the high discharge capacity and good cycling performance of $\mathrm{Li} / \mathrm{LiNi}_{0.1} \mathrm{Mg}_{0.1} \mathrm{Co}_{0.8} \mathrm{O}_{2}+$ fullerene-MWCNT cell.

\subsection{Cyclic Voltammetry of $\mathrm{Li} / \mathrm{LiNi}_{0.1} \mathrm{Mg}_{0.1} \mathrm{Co}_{0.8} \mathrm{O}_{2}$ and $\mathrm{Li} / \mathrm{LiNi}_{0.1} \mathrm{Mg}_{0.1} \mathrm{Co}_{0.8} \mathrm{O}_{2}$ +fullerene-MWCNT cells}

Cyclic Voltammetry (CV) curves of pristine $\mathrm{Li} / \mathrm{LiNi}_{0.1} \mathrm{Mg}_{0.1} \mathrm{Co}_{0.8} \mathrm{O}_{2}$ and $\mathrm{Li} / \mathrm{LiNi}_{0.1} \mathrm{Mg}_{0.1} \mathrm{Co}_{0.8} \mathrm{O}_{2} /$ fullerene-MWCNT composite cells containing $1 \mathrm{M} \mathrm{LiPF} 6$ in EC:DEC;1:1(v/v) measured between the potential range of $2.3 \mathrm{~V}$ and $4.5 \mathrm{~V}$ at a scan rate of $0.1 \mathrm{mV} / \mathrm{s}$ for the initial three cycles are shown in Fig. 8.

The CV curves for pristine $\mathrm{Li} / \mathrm{LiNi}_{0.1} \mathrm{Mg}_{0.1} \mathrm{Co}_{0.8} \mathrm{O}_{2}$ and $\mathrm{Li} / \mathrm{LiNi}_{0.1} \mathrm{Mg}_{0.1} \mathrm{Co}_{0.8} \mathrm{O}_{2}+$ fullerene-MWCNT composite electrodes show a pair of well-defined redox peaks and exhibit excellent electrochemical activity with a completely reversible process. A slightly broad oxidation and reduction peaks occurred at $4.12 \mathrm{~V}$ and $3.75 \mathrm{~V}$ for $\mathrm{Li} / \mathrm{LiNi}_{0.1} \mathrm{Mg}_{0.1} \mathrm{Co}_{0.8} \mathrm{O}_{2}$ cell (Fig.8a), whereas for $\mathrm{Li} / \mathrm{LiNi}_{0.1} \mathrm{Mg}_{0.1} \mathrm{Co}_{0.8} \mathrm{O}_{2}+$ fullerene-MWCNT cell (Fig.9b) the oxidation and reduction peaks occurred at $4.01 \mathrm{~V}$ and $3.82 \mathrm{~V}$ respectively corresponding to the $\mathrm{Ni}^{2+} / \mathrm{Ni}^{4+}$ redox couple. 
The polarization potential for the redox couple of $\mathrm{Li} / \mathrm{LiNi}_{0.1} \mathrm{Mg}_{0.1} \mathrm{Co}_{0.8} \mathrm{O}_{2}$ + fullereneMWCNT composite cell was found to be $0.19 \mathrm{~V}$ which is very much lesser than $0.37 \mathrm{~V}$ of $\mathrm{Li} / \mathrm{LiNi}_{0.1} \mathrm{Mg}_{0.1} \mathrm{Co}_{0.8} \mathrm{O}_{2}$ cell. With the addition of the fullerene-MWCNT hybrid, the electrode polarization of $\mathrm{LiNi}_{0.1} \mathrm{Mg}_{0.1} \mathrm{Co}_{0.8} \mathrm{O}_{2}$ has been significantly reduced resulting in an excellent electrochemical reversible process[3].

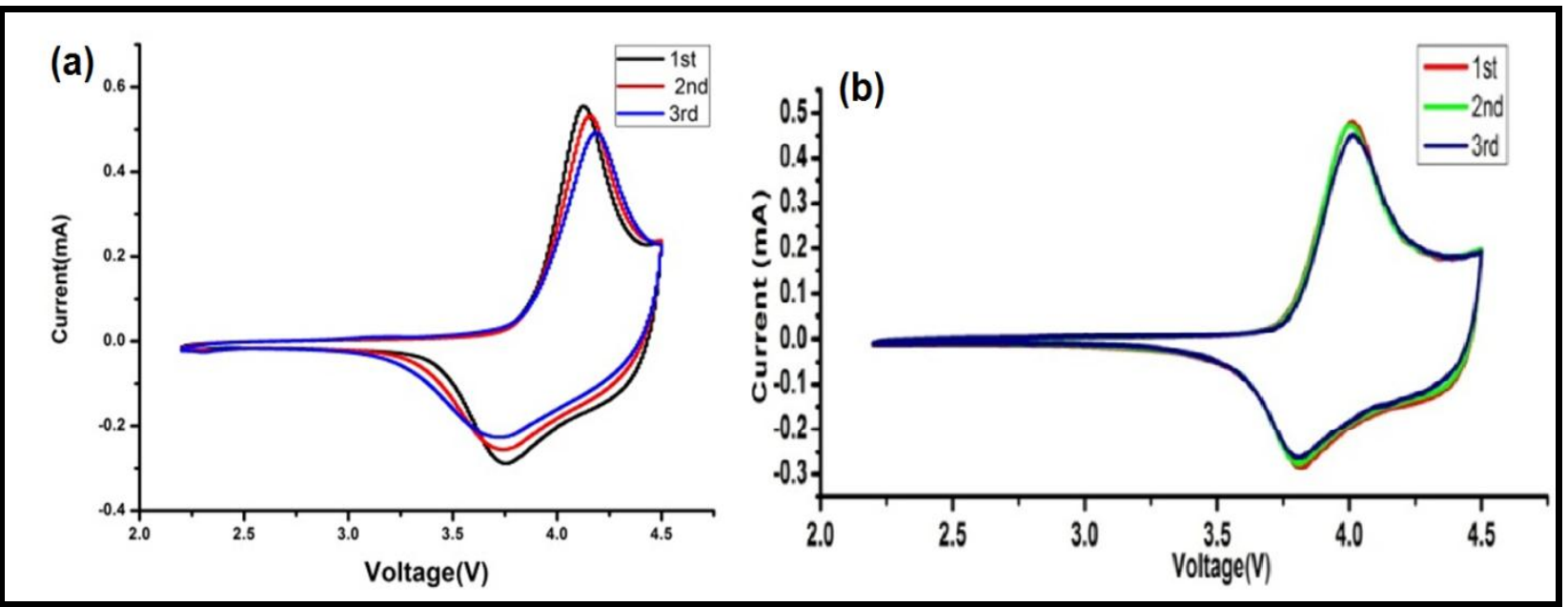

Fig. 8 Cyclic Voltammograms of (a) $\mathrm{Li} / \mathrm{LiNi}_{0.1} \mathrm{Mg}_{0.1} \mathrm{Co}_{0.8} \mathrm{O}_{2}$ and (b) $\mathrm{Li} / \mathrm{LiNi}_{0.1} \mathrm{Mg}_{0.1} \mathrm{Co}_{0.8} \mathrm{O}_{2}+$ fullerene- MWCNT composite cells containing $1 \mathrm{M} \mathrm{LiPF}_{6}$ in EC:DEC;1:1(v/v).

\subsection{Rate Capability and Cyclingbehaviour of $\mathrm{Li} / \mathrm{LiNi}_{0.1} \mathrm{Mg}_{0.1} \mathrm{Co}_{0.8} \mathrm{O}_{2}$ and} $\mathrm{Li} / \mathrm{LiNi}_{0.1} \mathrm{Mg}_{0.1} \mathrm{Co}_{0.8} \mathrm{O}_{2}+$ fullerene-MWCNT cells

The charge/discharge study was carried out for the assembled $\mathrm{Li} / \mathrm{LiNi}_{0.1} \mathrm{Mg}_{0.1} \mathrm{Co}_{0.8} \mathrm{O}_{2}$ and $\mathrm{Li} / \mathrm{LiNi}_{0.1} \mathrm{Mg}_{0.1} \mathrm{Co}_{0.8} \mathrm{O}_{2}+$ fullerene-MWCNT coin cells. Fig. 9(a) shows the typical galvanostatic charge-discharge cycling profile of $\mathrm{Mg}$-doped $\mathrm{Li}$ $/ \mathrm{LiNi}_{0.1} \mathrm{Mg}_{0.1} \mathrm{Co}_{0.8} \mathrm{O}_{2}$ cell containing $1 \mathrm{M} \mathrm{LiPF}_{6}$ in $\mathrm{EC}: \mathrm{DEC} ; 1: 1(\mathrm{v} / \mathrm{v})$ at $0.1 \mathrm{C}$ rate maintained at room temperature. A discharge capacity of $195 \mathrm{mAh} \mathrm{g}^{-1}$ and a charging capacity of 199 $\mathrm{mAh} \mathrm{g}^{-1}$ at its first cycle attaining $98 \%$ of its coulombic efficiency were seen with a reduction of discharge capacity to $186 \mathrm{mAh} \mathrm{g}^{-1}$ at its fifth cycle resulting in a fade-in capacity of $1.8 \mathrm{mAh} \mathrm{g}^{-1}$ per cycle. 
The rate capability of $\mathrm{Mg}$-doped $\mathrm{Li} / \mathrm{LiNi}_{0.1} \mathrm{Mg}_{0.1} \mathrm{Co}_{0.8} \mathrm{O}_{2}$ cell at different C-rates is shown in Fig. 9(b). For the $0.2 \mathrm{C}$ rate, the cell delivered a discharge capacity of $181 \mathrm{mAh} \mathrm{g}^{-1}$ with a charging capacity $173 \mathrm{mAh} \mathrm{g}^{-1}$ with $95 \%$ of coulombic efficiency. At higher C-rates the discharge capacity reduced to $152 \mathrm{mAh} \mathrm{g}^{-1}$ at $1 \mathrm{C}$ and $147 \mathrm{mAh} \mathrm{g}^{-1}$ at $2 \mathrm{C}$. The discharge capacity decreased with an increase in the C-rate.

The typical galvanostatic charge/discharge cycling profile of $\mathrm{Li} / \mathrm{LiNi}_{0.1} \mathrm{Mg}_{0.1} \mathrm{Co}_{0.8} \mathrm{O}_{2}+$ fullerene-MWCNT cell at $0.1 \mathrm{C}$ rate between 2.5 to $4.5 \mathrm{~V}$ is depicted in Fig.9(c). The cell was found to deliver a discharge capacity of $208 \mathrm{mAh} \mathrm{g}^{-1}$ with a charging capacity of $211 \mathrm{mAh} \mathrm{g}^{-1}$ during its first cycle with $99 \%$ of Coulombic efficiency, with a decrease of the discharge capacity to $202 \mathrm{mAh} \mathrm{g}^{-1}$ at its $5^{\text {th }}$ cycle with a fade in the capacity of $1.2 \mathrm{mAh} \mathrm{g}^{-1}$ per cycle. The rate capability of $\mathrm{Li} / \mathrm{LiNi}_{0.1} \mathrm{Mg}_{0.1} \mathrm{Co}_{0.8} \mathrm{O}_{2}+$ fullereneMWCNT cell investigated at $0.1 \mathrm{C}, 0.2 \mathrm{C}, 1 \mathrm{C}$, and $2 \mathrm{C}$ rates as shown in Fig. $9(\mathrm{~d})$. It is worth pointing out that the $\mathrm{Li} / \mathrm{LiNi}_{0.1} \mathrm{Mg}_{0.1} \mathrm{Co}_{0.8} \mathrm{O}_{2}+$ fullerene-MWCNT cell exhibited high discharge capacity and also less fade in capacity than pristine $\mathrm{Li} / \mathrm{LiNi}_{0.1} \mathrm{Mg}_{0.1} \mathrm{Co}_{0.8} \mathrm{O}_{2}$.

This unique $\mathrm{Li} / \mathrm{LiNi}_{0.1} \mathrm{Mg}_{0.1} \mathrm{Co}_{0.8} \mathrm{O}_{2}+$ fullerene-MWCNT cell provides a shorter lithium-ion diffusion path and good electronic conductivity, resulting in the demonstration of excellent electrochemical properties.The fullerene-MWCNT hybrid draped $\mathrm{LiNi}_{0.1} \mathrm{Mg}_{0.1} \mathrm{Co}_{0.8} \mathrm{O}_{2}$ nanocomposite favors an increased discharge capacity, facilitating the transfer of lithium ions across the active material/electrolyte interface, as well as the transfer of electrons from the current collector to the active material. 

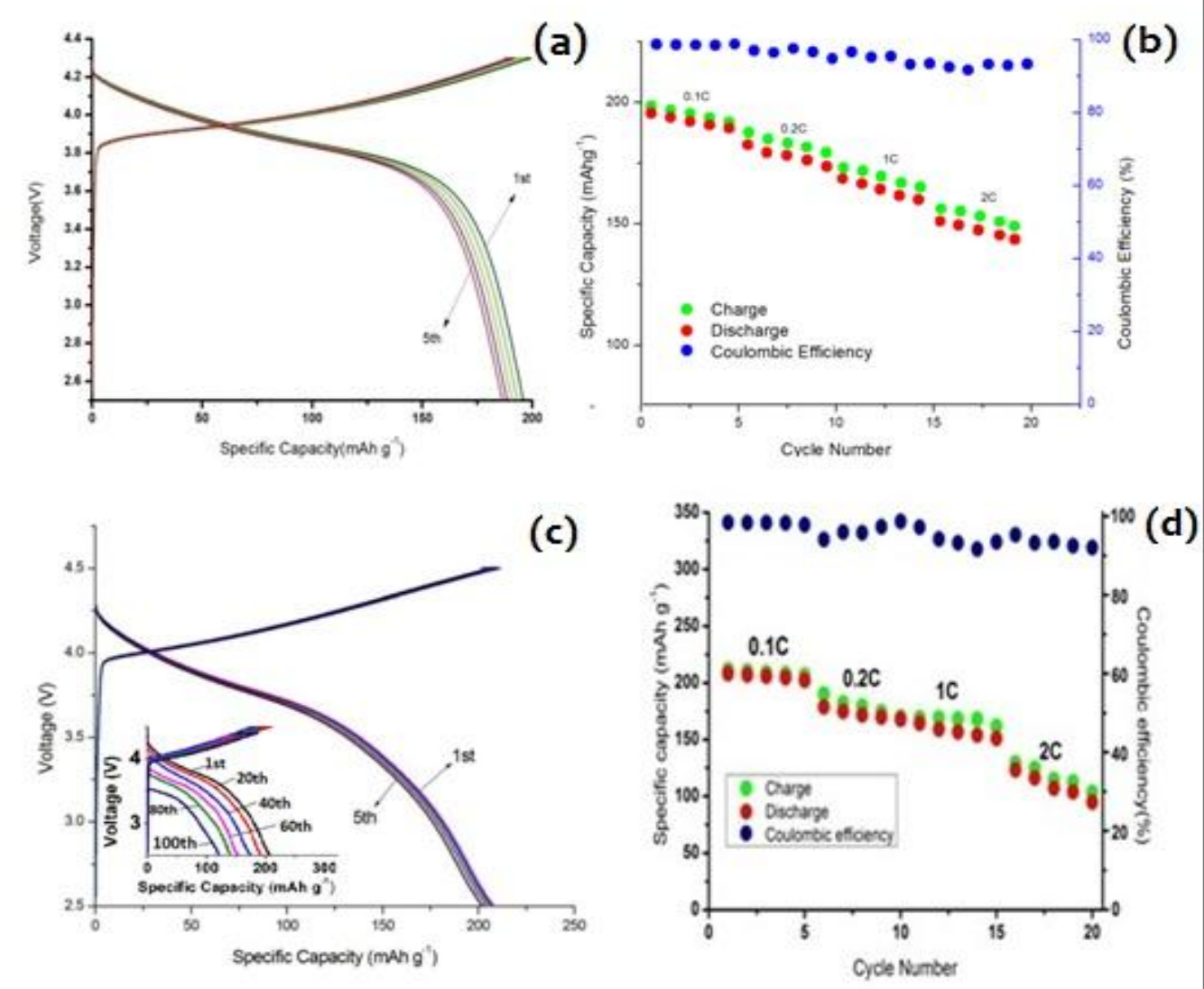

Fig. 9 (a) Cycling profile of $\mathrm{Li} / \mathrm{LiNi}_{0.1} \mathrm{Mg}_{0.1} \mathrm{Co}_{0.8} \mathrm{O}_{2}$ cell containing $1 \mathrm{M} \mathrm{LiPF} 6$ in EC:DEC;1:1(v/v) at $0.1 \mathrm{C}(\mathrm{b})$ Specific capacityVs cycle number of $\mathrm{Li} / \mathrm{LiNi}_{0.1} \mathrm{Mg}$ ${ }_{0.1} \mathrm{Co}_{0.8} \mathrm{O}_{2}$ cell $\quad$ (c) Cycling profile of $\mathrm{LiNi}_{0.1} \mathrm{Mg}_{0.1} \mathrm{Co}_{0.8} \mathrm{O}_{2}$ / fullerene- MWCNTcell containing $1 \mathrm{M} \mathrm{LiPF}_{6}$ in EC:DEC;1:1(v/v) at $0.1 \mathrm{C}$ at $0.1 \mathrm{C}$, Inset is the $20^{\text {th }}, 40^{\text {th }}, 60^{\text {th }}, 80^{\text {th }}$, and $100^{\text {th }}$ cycling profile and (d) Specific capacity $\mathrm{Vs}$ cycle number of $\mathrm{Li} /$ $\mathrm{LiNi}_{0.1} \mathrm{Mg}_{0.1} \mathrm{Co}_{0.8} \mathrm{O}_{2}+$ fullerene- MWCNT cell

In addition, the factors that may have contributed to the superior electrochemical performance of the fullerene-MWCNT hybrid draped $\mathrm{LiNi}_{0.1} \mathrm{Mg}_{0.1} \mathrm{Co}_{0.8} \mathrm{O}_{2}$ nanocomposite electrode are improvement in the structural stability, a decrease in the disorder of metal ions in the lattice, suppression of the dissolution of transition-metal ions, and phase transitions, removal of HF from the electrolyte solution, and a reduced amount of heat production during charge-discharge processes. Also, the improved electrochemical performance of the fullerene-MWCNT hybrid draped $\mathrm{LiNi}_{0.1} \mathrm{Mg}_{0.1} \mathrm{Co}_{0.8} \mathrm{O}_{2}$ nanocomposite was attributed to an increase in the grain connectivity and high electronic conductivity. The good elasticity 
between the graphene layers of MWCNT can buffer the volume changes of the oxide materials, inhibit the agglomeration between the oxides and the powdered electrode materials, and obviously improve the cycling performance of the electrode materials.

\subsection{Impedance Spectroscopy of $\mathrm{Li} / \mathrm{LiNi}_{0.1} \mathrm{Mg}_{0.1} \mathrm{Co}_{0.8} \mathrm{O}_{2}$ and $\mathrm{Li} / \mathrm{LiNi}_{0.1} \mathrm{Mg}_{0.1} \mathrm{Co}_{0.8} \mathrm{O}_{2}+$ fullerene-MWCNT cells}

Electrochemical impedance spectroscopy analysis further confirms the beneficial effect of the integrated fullerene-MWCNT hybrid in enhancing the electrochemical efficiency of the $\mathrm{Li} / \mathrm{LiNi}_{0.1} \mathrm{Mg}_{0.1} \mathrm{Co}_{0.8} \mathrm{O}_{2}+$ fullerene-MWCNT cell relative to that of the pristine $\mathrm{Li} / \mathrm{LiNi}_{0.1} \mathrm{Mg}_{0.1} \mathrm{Co}_{0.8} \mathrm{O}_{2}$ cell.
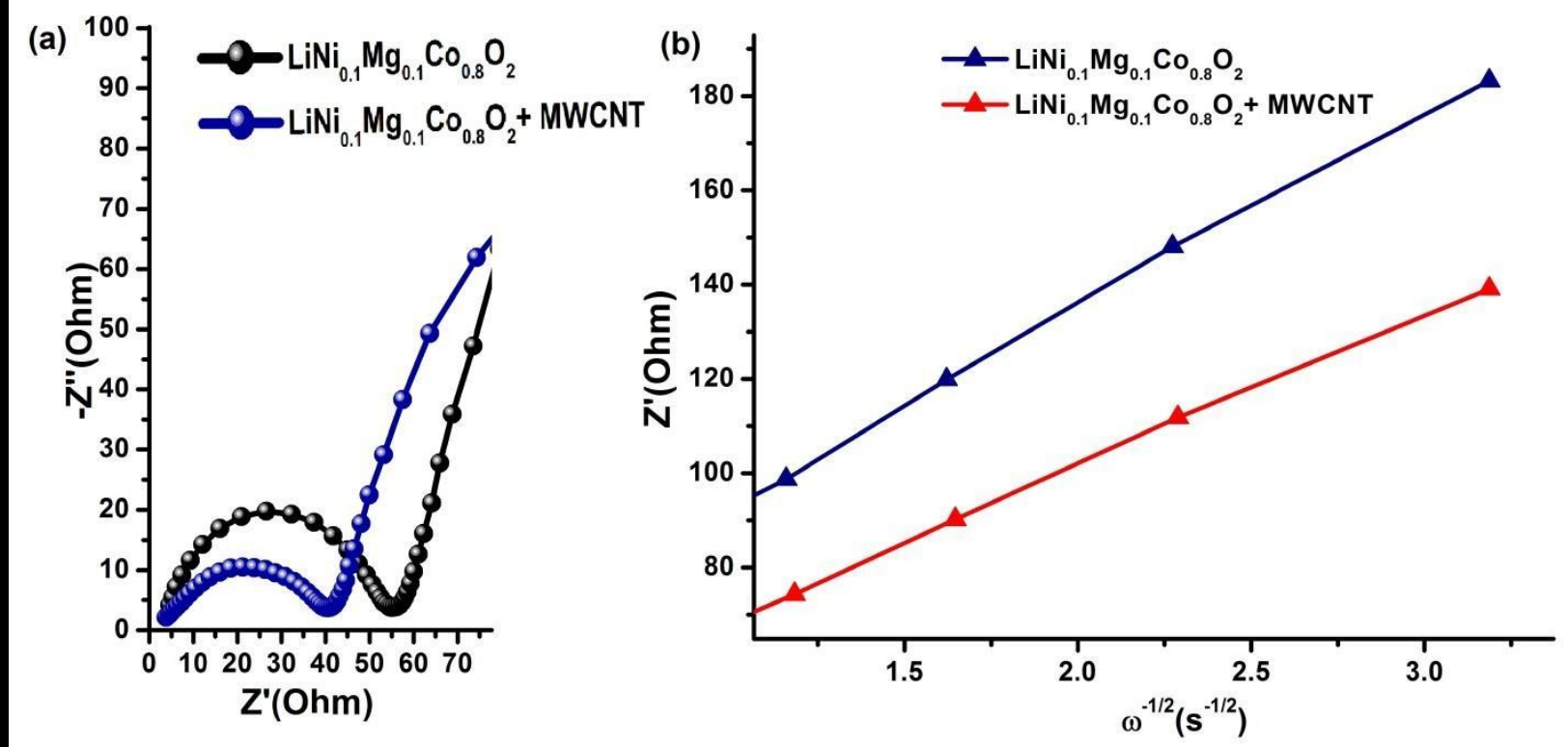

Fig. 10(a) Nyquist plots of $\mathrm{LiNi}_{0.1} \mathrm{Mg}_{0.1} \mathrm{Co}_{0.8} \mathrm{O}_{2}$ and $\mathrm{LiNi}_{0.1} \mathrm{Mg}_{0.1} \mathrm{Co}_{0.8} \mathrm{O}_{2}$ / fullerene- MWCNT cell and (b) Plot between $Z^{\prime}$ and $\omega^{-1 / 2}$ for $\mathrm{LiNi}_{0.1} \mathrm{Mg}_{0.1} \mathrm{Co}_{0.8} \mathrm{O}_{2}$ and $\mathrm{LiNi}_{0.1} \mathrm{Mg}_{0.1} \mathrm{Co}_{0.8} \mathrm{O}_{2} /$ fullereneMWCNT cell

Fig 10(a) shows the Nyquist plot of the $\mathrm{Li} / \mathrm{LiNi}_{0.1} \mathrm{Mg}_{0.1} \mathrm{Co}_{0.8} \mathrm{O}_{2}$ and $\mathrm{Li} / \mathrm{LiNi}_{0.1} \mathrm{Mg}_{0.1} \mathrm{Co}_{0.8} \mathrm{O}_{2}+$ fullerene-MWCNT cell recorded between $200 \mathrm{kHz}$ to $100 \mathrm{mHz}$. The semicircle observed at the high-frequency area correlates with the mobility of lithium ions 
across the surface film[25]. The leaning line was a clear indicator of the Warburg behaviorandwas observed at the low-frequency side owing to the process of $\mathrm{Li}^{+}$ions diffusion through the synthesized cathode materials. The $\mathrm{Li} / \mathrm{LiNi}_{0.1} \mathrm{Mg}_{0.1} \mathrm{Co}_{0.8} \mathrm{O}_{2}+$ fullerene-MWCNT cell recorded a lower $R_{\text {ct }}$ value of $40.4 \Omega$ when compared with $\mathrm{LiNi}_{0.1} \mathrm{Mg}_{0.1} \mathrm{Co}_{0.8} \mathrm{O}_{2} \quad\left(R_{\mathrm{ct}}=\right.$ $55.03 \Omega$ ), suggesting that the presence of fullerene-MWCNT hybrid facilitates the Li-ion diffusion process in $\mathrm{LiNi}_{0.1} \mathrm{Mg}_{0.1} \mathrm{Co}_{0.8} \mathrm{O}_{2}$. The Warburg factor $\sigma$ was calculated from the impedance spectra using equation (1)

$$
Z^{\prime}=R_{s}+R_{c t}+\sigma \omega^{-1 / 2}
$$

in which $\omega, R_{\mathrm{s}}$, and $\mathrm{R}_{\mathrm{ct}}$ represent the angular frequency, solution resistance, and charge transfer resistance respectively [26]. The Lithium diffusion coefficient $D$ was calculated using equation (2)

$$
D=\frac{R^{2} T^{2}}{2 n^{4} A^{2} F^{4} C^{2} \sigma^{2}}
$$

in which the parameters $R, A, T, F, C, \sigma$ and $n$ represent the universal gas constant, the surface area of the as-prepared cathode, absolute temperature, Faraday constant, lithium-ion concentration, Warburg factor, and the number of electrons/ molecule in oxidation process respectively[27]. The Warburg factor was calculated from the graphical plot between Z' and $\omega^{-1 / 2}$ as shown in Fig 10(b). Using the calculated value of the Warburg factor $\sigma$, lithium diffusion coefficients were determined and tabulated in Table 1. Using equation (3) exchange current density $I_{o}$ was calculated[26]

$$
I_{O}=\frac{R T}{n R_{c t} F} \rightarrow \text { (3) }
$$




\begin{tabular}{|c|c|c|c|}
\hline System & $\sigma\left(\Omega s^{1 / 2}\right)$ & $\mathrm{D}\left(\mathrm{cm}^{2} \mathrm{~s}^{-1}\right)$ & $I_{0}\left(m A g^{-1}\right)$ \\
\hline $\mathrm{LiNi}_{0.1} \mathrm{Mg}_{0.1} \mathrm{Co}_{0.8} \mathrm{O}_{2}$ & 43.35 & $5.13 \times 10^{-13}$ & 42.74 \\
\hline $\begin{array}{l}\mathrm{LiNi}_{0.1} \mathrm{Mg}_{0.1} \mathrm{Co}_{0.8} \mathrm{O}_{2} \\
\text { fullerene- MWCNT }\end{array}$ & 34.09 & $8.31 \times 10^{-13}$ & 58.22 \\
\hline
\end{tabular}

Table 1: Calculated values of Warburg factor, Lithium diffusion coefficient, and exchange current density of $\mathrm{LiNi}_{0.1} \mathrm{Mg}_{0.1} \mathrm{Co}_{0.8} \mathrm{O}_{2}$ and $\mathrm{LiNi}_{0.1} \mathrm{Mg}_{0.1} \mathrm{Co}_{0.8} \mathrm{O}_{2}$ / fullerene-MWCNT

The lithium diffusion coefficient increased from $5.13 \times 10^{-13}$ to $8.31 \times 10^{-13} \mathrm{~cm}^{2} \mathrm{~s}^{-1}$ due to the surface modification of pristine $\mathrm{LiNi}_{0.1} \mathrm{Mg}_{0.1} \mathrm{Co}_{0.8} \mathrm{O}_{2}$ by fullerene-MWCNT hybrid. Also, the exchange current density increased from $42.74 \mathrm{~mA} \mathrm{~g}^{-1}$ for pristine $\mathrm{LiNi}_{0.1} \mathrm{Mg}_{0.1} \mathrm{Co}_{0.8} \mathrm{O}_{2}$ to $58.22 \mathrm{~mA} \mathrm{~g}^{-1}$, due to the improved kinetics of the Li insertion /extraction process for the $\mathrm{LiNi}_{0.1} \mathrm{Mg}_{0.1} \mathrm{Co}_{0.8} \mathrm{O}_{2} /$ fullerene- MWCNT composite.

The EIS results suggest that incorporation of fullerene- MWCNT hybrid in $\mathrm{LiNi}_{0.1} \mathrm{Mg}_{0.1} \mathrm{Co}_{0.8} \mathrm{O}_{2}$ cathode material decreases the charge transfer resistance more effectively than pristine $\mathrm{LiNi}_{0.1} \mathrm{Mg}_{0.1} \mathrm{Co}_{0.8} \mathrm{O}_{2}$. The unique nanostructured fullerene-MWCNT hybrid draped $\mathrm{LiNi}_{0.1} \mathrm{Mg}_{0.1} \mathrm{Co}_{0.8} \mathrm{O}_{2}$ composite material was found to greatly improve the storage capacity of lithium ions and the cycle stability of the battery. The electrochemical properties of fullerene-MWCNT hybrid draped $\mathrm{LiNi}_{0.1} \mathrm{Mg}_{0.1} \mathrm{Co}_{0.8} \mathrm{O}_{2}$ composite are closely related to their structures. The edges and defects present in graphene layers provide enough space for storing lithium ions. The excellent conductivity of graphene provides its composites with excellent lithium storage capacities and enhanced electrochemical performances.

Enhanced charge transfer is attributed to the fullerene-MWCNT hybrid network, decorating the surface of $\mathrm{LiNi}_{0.1} \mathrm{Mg}_{0.1} \mathrm{Co}_{0.8} \mathrm{O}_{2}$ cathode material. The inclusion of fullereneMWCNT hybrid in the layered $\mathrm{LiNi}_{0.1} \mathrm{Mg}_{0.1} \mathrm{Co}_{0.8} \mathrm{O}_{2}$ cathodic material demonstrates a good reversibility cycle, enhanced charge transfer kinetics, improved lithium-ion diffusion at 
lithiation and de-lithiation, and good structural stability of the layered cathode material for lithium-ion batteries.

\section{Conclusion}

We have synthesized successfully a novel nanocomposite material by interweaving the layered $\mathrm{LiNi}_{0.1} \mathrm{Mg}_{0.1} \mathrm{Co}_{0.8} \mathrm{O}_{2}$ within the fullerene-MWCNT hybrid matrix using a simple chemical route. Promising results were obtained by modifying the cathode with a fullereneMWCNT hybrid. Layer-structured $\mathrm{LiNi}_{0.1} \mathrm{Mg}_{0.1} \mathrm{Co}_{0.8} \mathrm{O}_{2} /$ fullerene-MWCNT composite cathode material with good hexagonal ordering was evident from XRD and Raman studies. The FESEM images of $\mathrm{LiNi}_{0.1} \mathrm{Mg}_{0.1} \mathrm{Co}_{0.8} \mathrm{O}_{2} /$ fullerene- MWCNT composite shows the cubical shaped $\mathrm{LiNi}_{0.1} \mathrm{Mg}_{0.1} \mathrm{Co}_{0.8} \mathrm{O}_{2}$ particles embedded with the transparent MWCNT which enhanced the electrochemical properties of the cathode. The existence of strong bonding between MWCNTs and $\mathrm{LiNi}_{0.1} \mathrm{Mg}_{0.1} \mathrm{Co}_{0.8} \mathrm{O}_{2}$ composite was evident from HRTEM which revealed the well-dispersed nature of $\mathrm{LiNi}_{0.1} \mathrm{Mg}_{0.1} \mathrm{Co}_{0.8} \mathrm{O}_{2}$ particles, bound onto the spherical fullerene molecules, and enwrapped by the transparent MWCNT. Facilitated by the interconnecting and conductive fullerene-MWCNT hybrid network, this newly designed nanocomposite material offers a significantly larger initial discharge capacity of 208mAhg ${ }^{1}$ with good cycling stability and stable electrochemical reversibility. As fullerene-MWCNT hybrid improves the particle-particle connectivity, it constructs an efficient Li-ion and electron channel, which significantly enhances the Li-ion diffusion rate and reduces the charge transfer resistance. The $\mathrm{R}_{\mathrm{ct}}$ value of the $\mathrm{Li} / \mathrm{LiNi}_{0.1} \mathrm{Mg}_{0.1} \mathrm{Co}_{0.8} \mathrm{O}_{2}+$ fullerene-MWCNT cell $(40.4 \Omega)$ is much lower than that of the pristine $\mathrm{Li} / \mathrm{LiNi}_{0.1} \mathrm{Mg}_{0.1} \mathrm{Co}_{0.8} \mathrm{O}_{2}$ cell

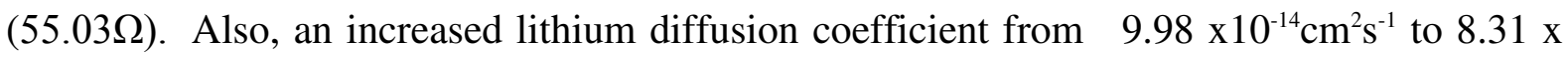
$10^{-13} \mathrm{~cm}^{2} \mathrm{~s}^{-1}$ was evident for the $\mathrm{Li} / \mathrm{LiNi}_{0.1} \mathrm{Mg}_{0.1} \mathrm{Co}_{0.8} \mathrm{O}_{2}+$ fullerene- MWCNT cell. The promising results of our study with an emphasis on doping and surface modification highlighted that the 
synergistic effect that occurs between $\mathrm{LiNi}_{0.1} \mathrm{Mg}_{0.1} \mathrm{Co}_{0.8} \mathrm{O}_{2}$ and fullerene-MWCNT hybrid, pave way for the substantial improvement in the electrode performance in high capacity lithium batteries.

\section{Declarations}

\section{Funding}

Not applicable.

\section{Conflicts of interest}

The authors declare that they have no known competing financial interests or personal relationships that could have appeared to influence the work reported in this research paper.

\section{Availability of data and material}

Not applicable.

\section{References}

[1] X. Meng, Recent Progress of Graphene as Cathode materials in Lithium Ion Batteries. IOP Conf. Ser. Earth Environ. Sci. 300, 042039( 2019).https:// doi: 10.1088/17551315/300/4/042039.

[2] D. Di Lecce et al, Multiwalled Carbon Nanotubes Anode in Lithium-Ion Battery with $\mathrm{LiCoO}_{2}, \mathrm{Li}\left[\mathrm{Ni}_{1 / 3} \mathrm{Co}_{1 / 3} \mathrm{Mn}_{1 / 3}\right] \mathrm{O}_{2}$ and $\mathrm{LiFe}_{1 / 4} \mathrm{Mn}_{1 / 2} \mathrm{Co}_{1 / 4} \mathrm{PO}_{4}$ Cathodes. ACS Sustain. Chem. Eng.6, 3225-3232 ( 2018). https:// doi: 10.1021/acssuschemeng.7b03395.

[3] S. S. Jan, S. Nurgul, X. Shi, H. Xia, and H. Pang,Improvement of electrochemical performance of $\mathrm{LiNi}_{0.8} \mathrm{Co}_{0.1} \mathrm{Mn}_{0.1} \mathrm{O}_{2}$ cathode material by graphene nanosheets modification. Electrochim. Acta.149, 86-93(2014). https:// doi: 10.1016/j.electacta.2014.10.093.

[4] A. Hakimian, S. Kamarthi, S. Erbis, K. M. Abraham, T. P. Cullinane, and J. A. Isaacs, 
Economic analysis of CNT lithium-ion battery manufacturing. Environ. Sci. Nano.2, . 463-476( 2015). https://doi: 10.1039/C5EN00078E.

[5] X. Li et al., Improved rate capability of a $\mathrm{LiNi}_{1 / 3} \mathrm{Co}_{1 / 3} \mathrm{Mn}_{1 / 3} \mathrm{O}_{2} / \mathrm{CNT} /$ graphene hybrid material for Li-ion batteries. RSC Adv.7, 24359-24367(2017). https://doi: 10.1039/C7RA03438E.

[6] W. Koh, J. I. Choi, S. G. Lee, W. R. Lee, and S. S. Jang, First-principles study of Li adsorption in a carbon nanotube-fullerene hybrid system. Carbon N. Y. 49, 286-293 ( 2011). https://doi: 10.1016/j.carbon.2010.09.022.

[7] K.-C. Jiang, S. Xin, J.-S. Lee, J. Kim, X.-L. Xiao, and Y.-G. Guo,Improved kinetics of $\mathrm{LiNi}_{1 / 3} \mathrm{Mn}_{1 / 3} \mathrm{Co}_{1 / 3} \mathrm{O}_{2}$ cathode material through reduced graphene oxide networks. Phys. Chem. Chem. Phys.14, 2934( 2012). https:// doi: 10.1039/c2cp23363k.

[8] R. Pongilat and K. Nallathamby,A novel $\mathrm{Li}_{2} \mathrm{Mn}_{2.9} \mathrm{Ni}_{0.9} \mathrm{Co}_{0.2} \mathrm{O}_{8}$ spinel composite interweaved with carbon nanotube architecture as a lithium battery cathode," RSC Adv.6, 49198-49205( 2016). https:// doi: 10.1039/C6RA04344E.

[9] H. Zhang,Synthesis and Characterization of $\mathrm{LiNi}_{0.7-x} \mathrm{Mg}_{x} \mathrm{Co}_{0.3} \mathrm{O}_{2}(0 \leq x \leq 0.1)$ Cathode Materials for Lithium-Ion Batteries Prepared by a Sol-Gel Method. Adv. Mater. Sci. Eng.2014, 1-7(2014). https://doi: 10.1155/2014/746341.

[10] J. Xiang, C. Chang, F. Zhang, and J. Sun, Rheological Phase Synthesis and Electrochemical Properties of $\mathrm{Mg}$-Doped $\mathrm{LiNi}_{0.8} \mathrm{Co}{ }_{0.2} \mathrm{O}_{2}$ Cathode Materials for Lithium-Ion Battery. J. Electrochem. Soc.155,( 2008) https://doi: 10.1149/1.2917213.

[11] J. Cho and B. Park, Preparation and electrochemical/thermal properties of $\mathrm{LiNi}_{0.74} \mathrm{Co}_{0.26} \mathrm{O}_{2}$ cathode material, J. Power Sources.92, 35-39( 2001).https:// doi: 10.1016/S0378-7753(00)00499-7.

[12] H. Zhang et al., Recent progress in advanced electrode materials, separators and electrolytes for lithium batteries, J. Mater. Chem. A.6,20564-20620( 2018). https://doi: 
10.1039/C8TA05336G.

[13] R. Robert, C. Villevieille, and P. Novák,Enhancement of the high potential specific charge in layered electrode materials for lithium-ion batteries, J. Mater. Chem. A.2, 8589(2014). https://doi: 10.1039/c3ta12643a.

[14] K. Yin, W. Fang, B. Zhong, X. Guo, Y. Tang, and X. Nie, The effects of precipitant agent on structure and performance of $\mathrm{LiNi}_{1 / 3} \mathrm{Co}_{1 / 3} \mathrm{Mn}_{1 / 3} \mathrm{O}_{2}$ cathode material via a carbonate co-precipitation method. Electrochim. Acta. 85,99-103(2012). https://doi: 10.1016/j.electacta.2012.06.064.

[15] J. Wang, R. Ran, M. O. Tade, and Z. Shao, Self-assembled mesoporous $\mathrm{TiO}_{2} /$ carbon nanotube composite with a three-dimensional conducting nanonetwork as a high-rate anode material for lithium-ion battery. J. Power Sources. 254,18-28(2014). https://doi: 10.1016/j.jpowsour.2013.12.090.

[16] C. Julien,Electrochemical performances of layered $\mathrm{LiM}_{1-\mathrm{y}} \mathrm{M}_{\mathrm{y}^{\prime}} \mathrm{O}_{2}\left(\mathrm{M}=\mathrm{Ni}, \mathrm{Co} ; \mathrm{M}^{\prime}=\mathrm{Mg}\right.$, Al, B) oxides in lithium batteries. Solid State Ionics.135, 121-130( 2000). https://doi: 10.1016/S0167-2738(00)00290-3.

[17] P. Kalyani and N. Kalaiselvi,Various aspects of $\mathrm{LiNiO}_{2}$ chemistry: A review. Sci. Technol. Adv. Mater. 6,689-703(2005). https://doi: 10.1016/j.stam.2005.06.001.

[18] N. H. Metwally, G. R. Saad, and E. A. Abd El-Wahab, Grafting of multiwalled carbon nanotubes with pyrazole derivatives: characterization, antimicrobial activity and molecular docking study. Int. J. Nanomedicine.14, 6645-6659( 2019). https://doi: 10.2147/IJN.S182699.

[19] Z. Fang et al., "Facile scalable synthesis of $\mathrm{Co}_{3} \mathrm{O}_{4} /$ carbon nanotube hybrids as superior anode materials for lithium-ion batteries. Mater. Res. Bull.48, 4419-4423( 2013). https://doi: 10.1016/j.materresbull.2013.06.044.

[20] T. Drezen, N.-H. Kwon, P. Bowen, I. Teerlinck, M. Isono, and I. Exnar, Effect of 
particle size on $\mathrm{LiMnPO}_{4}$ cathodes. J. Power Sources.174, 949-953( 2007). https://doi: 10.1016/j.jpowsour.2007.06.203.

[21] M. Inaba, Y. Iriyama, Z. Ogumi, Y. Todzuka, and A. Tasaka, "Raman study of layered rock-salt $\mathrm{LiCoO}_{2}$ and its electrochemical lithium deintercalation. J. Raman Spectrosc. 28,613-617(1997). https://doi: 10.1002/(SICI)1097-4555(199708)28:8<613::AIDJRS138>3.0.CO;2-T.

[22] A. Hasanzadeh, A. Khataee, M. Zarei, and Y. Zhang, Two-electron oxygen reduction on fullerene $\mathrm{C}_{60}$-carbon nanotubes covalent hybrid as a metal-free electrocatalyst. Sci. Rep.9,13780( 2019). https://doi: 10.1038/s41598-019-50155-7.

[23] A. C. Ferrari and J. Robertson, Raman spectroscopy of amorphous, nanostructured, diamond-like carbon, and nanodiamond. Philos. Trans. R. Soc. London. Ser. A Math. Phys. Eng. Sci.362, 2477-2512( 2004) https://doi: 10.1098/rsta.2004.1452.

[24] Y. Ma, P. Cui, D. Zhan, B. Gan, Y. Ma, and Y. Liang, Enhancement of the Electrochemical Performance of $\mathrm{LiNi}_{1 / 3} \mathrm{Co}_{1 / 3} \mathrm{Mn}_{1 / 3} \mathrm{O}_{2}$ Cathode Material by DoubleLayer Coating with Graphene Oxide and $\mathrm{SnO}_{2}$ for Lithium-Ion Batteries. J. Nanomater.2019,1-10( 2019). https://doi: 10.1155/2019/7586790.

[25] H.-M. Cho, M. V. Chen, A. C. MacRae, and Y. S. Meng,Effect of Surface Modification on Nano-Structured $\mathrm{LiNi}_{0.5} \mathrm{Mn}_{1.5} \mathrm{O}_{4}$ Spinel Materials. ACS Appl. Mater. Interfaces.7, 16231-16239(2015). https://doi: 10.1021/acsami.5b01392.

[26] A. Kumar et al., $\mathrm{Mg}$ doped $\mathrm{Li}_{2} \mathrm{FeSiO}_{4} / \mathrm{C}$ nanocomposites synthesized by the solvothermal method for lithium ion batteries. Dalt. Trans. 46, 12908-12915( 2017). https://doi: 10.1039/C7DT03177G.

[27] L. Qu et al., Mg-doped $\mathrm{Li}_{2} \mathrm{FeSiO}_{4} / \mathrm{C}$ as high-performance cathode material for lithiumion battery. J. Power Sources. 307,69-76(2016). https://doi: 10.1016/j.jpowsour.2015.12.137. 


\section{Figures}

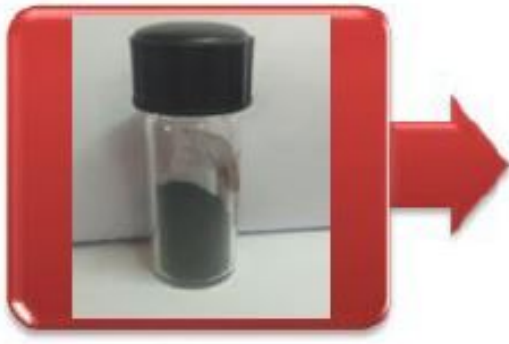

Active material

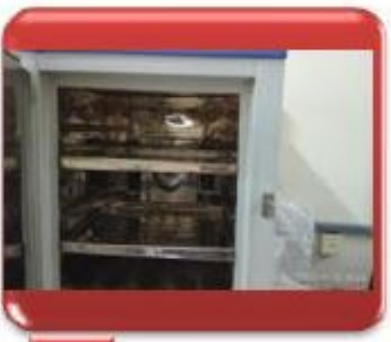

Dried at $80^{\circ} \mathrm{C}$
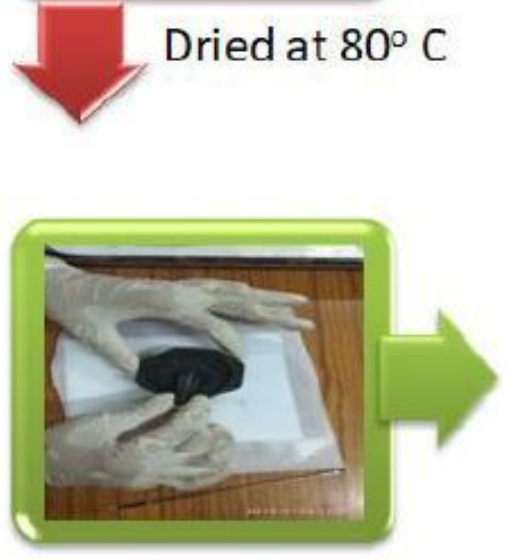

Slurry

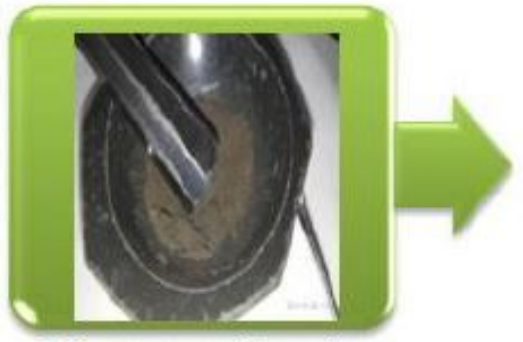

Mixture of active material + fullerene MWCNT

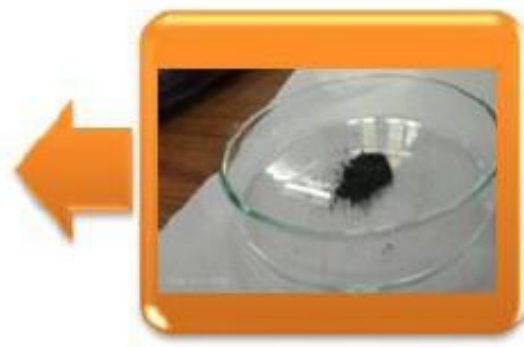

Nanocomposite cathode material

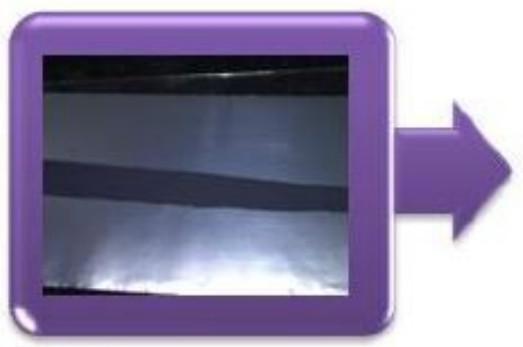

Coating

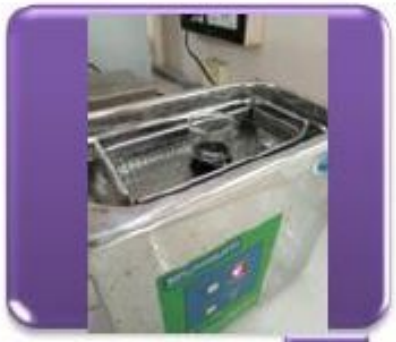

Ultra-sonication

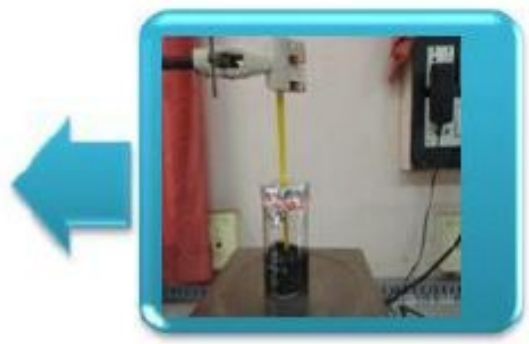

Vigorous stirring at $50^{\circ} \mathrm{C}$

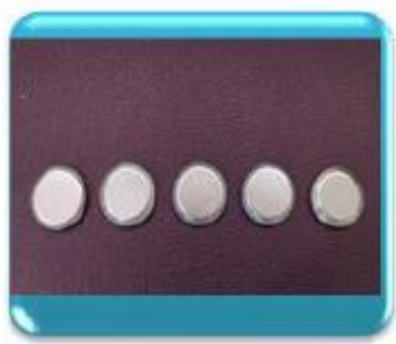

Coincells

\section{Figure 1}

The schematic diagram of the process involved in the preparation of the LiNi0.1Mg0.1Co0.802 / fullerene-MWCNT nanocomposite and its coin cells 


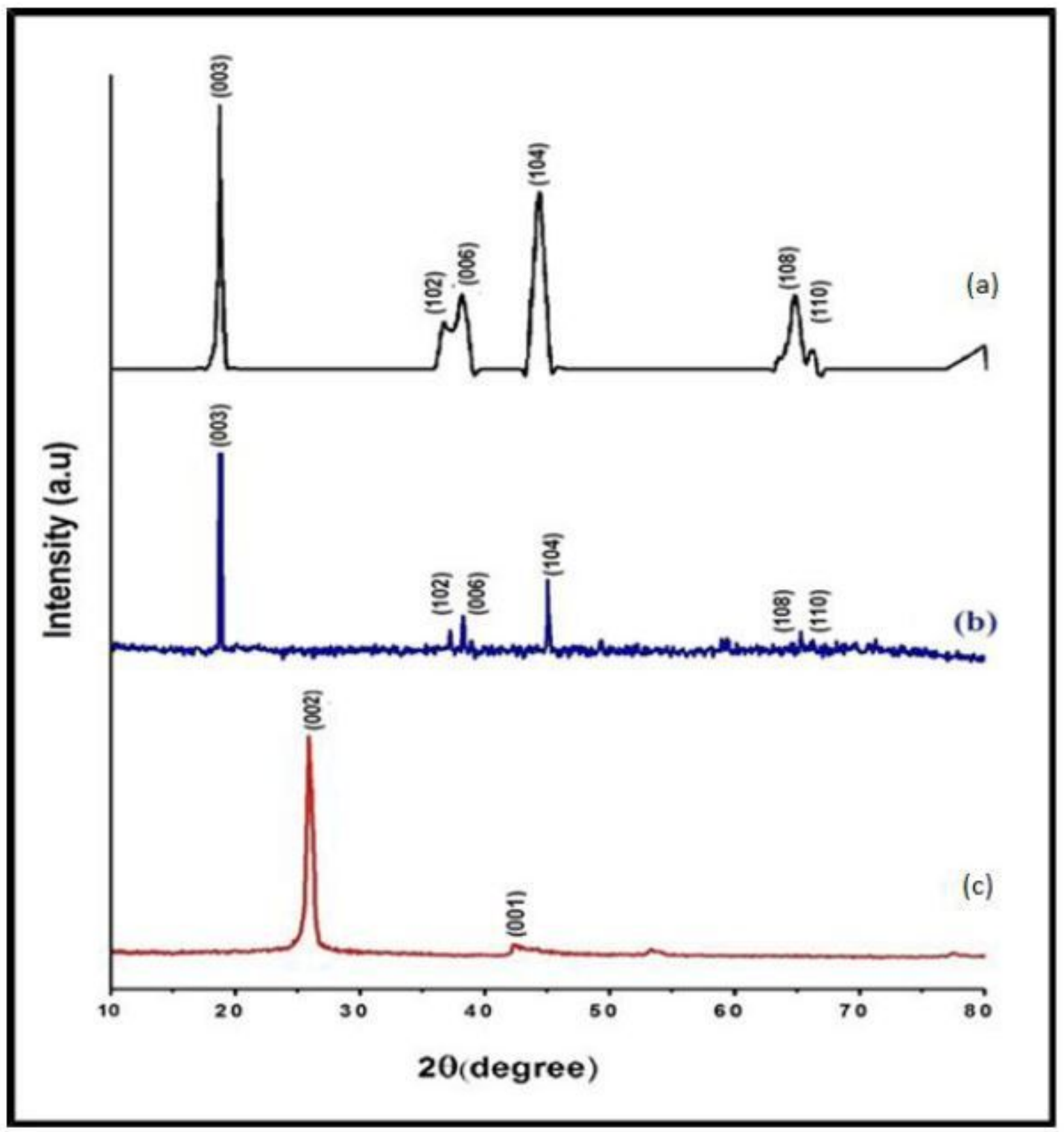

Figure 2

XRD pattern of (a) LiNi0.1Mg0.1Co0.8O2 (b) fullerene-MWCNT hybrid draped LiNi0.1Mg0.1Co0.8O2 and (c) fullerene-MWCNT hybrid 


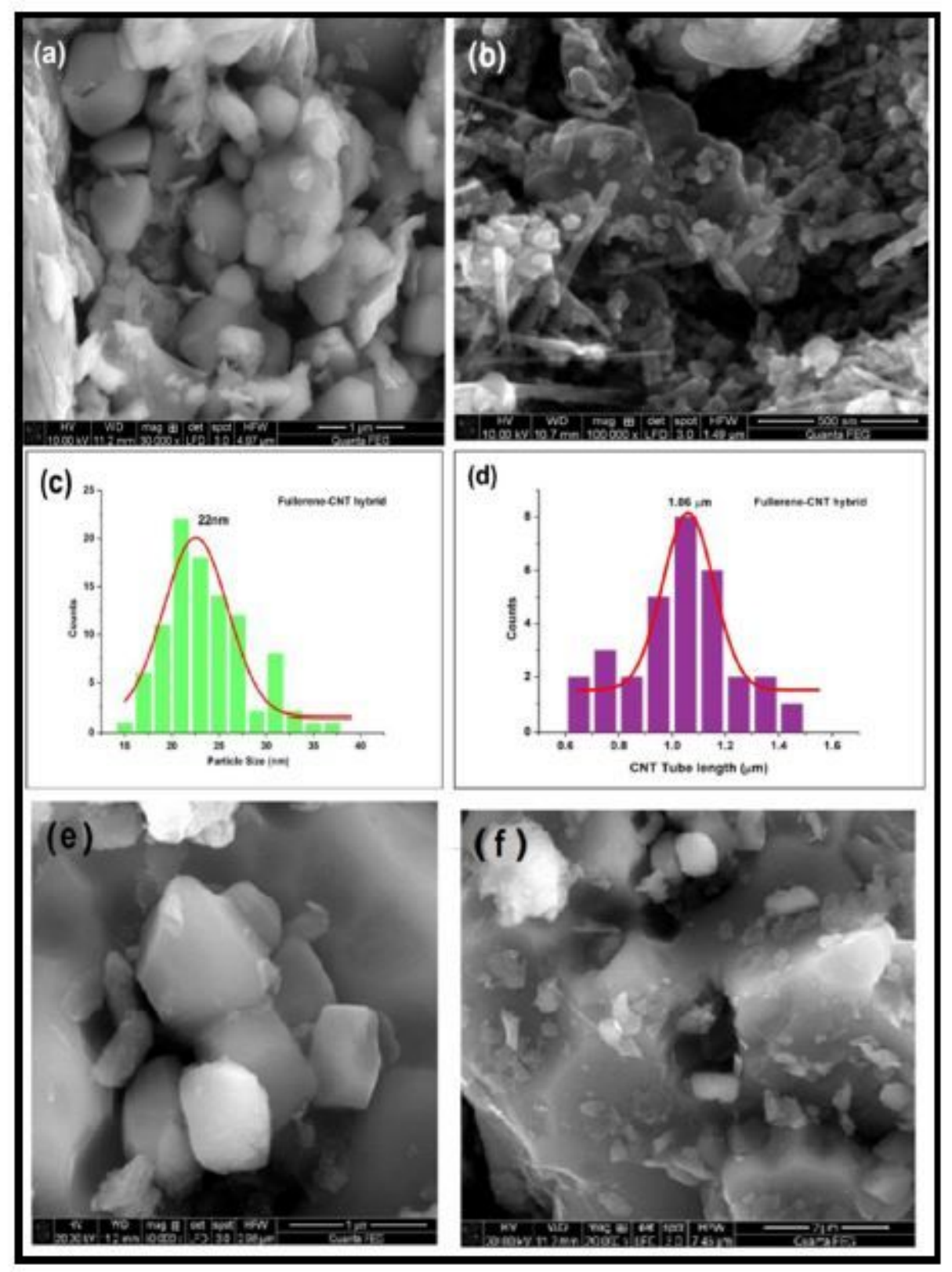

Figure 3

FESEM images of (a) LiNi0.1Mg0.1 Co0.802 (b) fullerene-MWCNT hybrid (c) Histogram of the particle size distribution in fullerene- MWCNT hybrid (d) Histogram of the MWCNT length distribution in fullereneMWCNT hybrid (e) and (f) fullerene- MWCNT hybrid draped LiNi0.1Mg0.1Co0.8O2 at different dimensions 


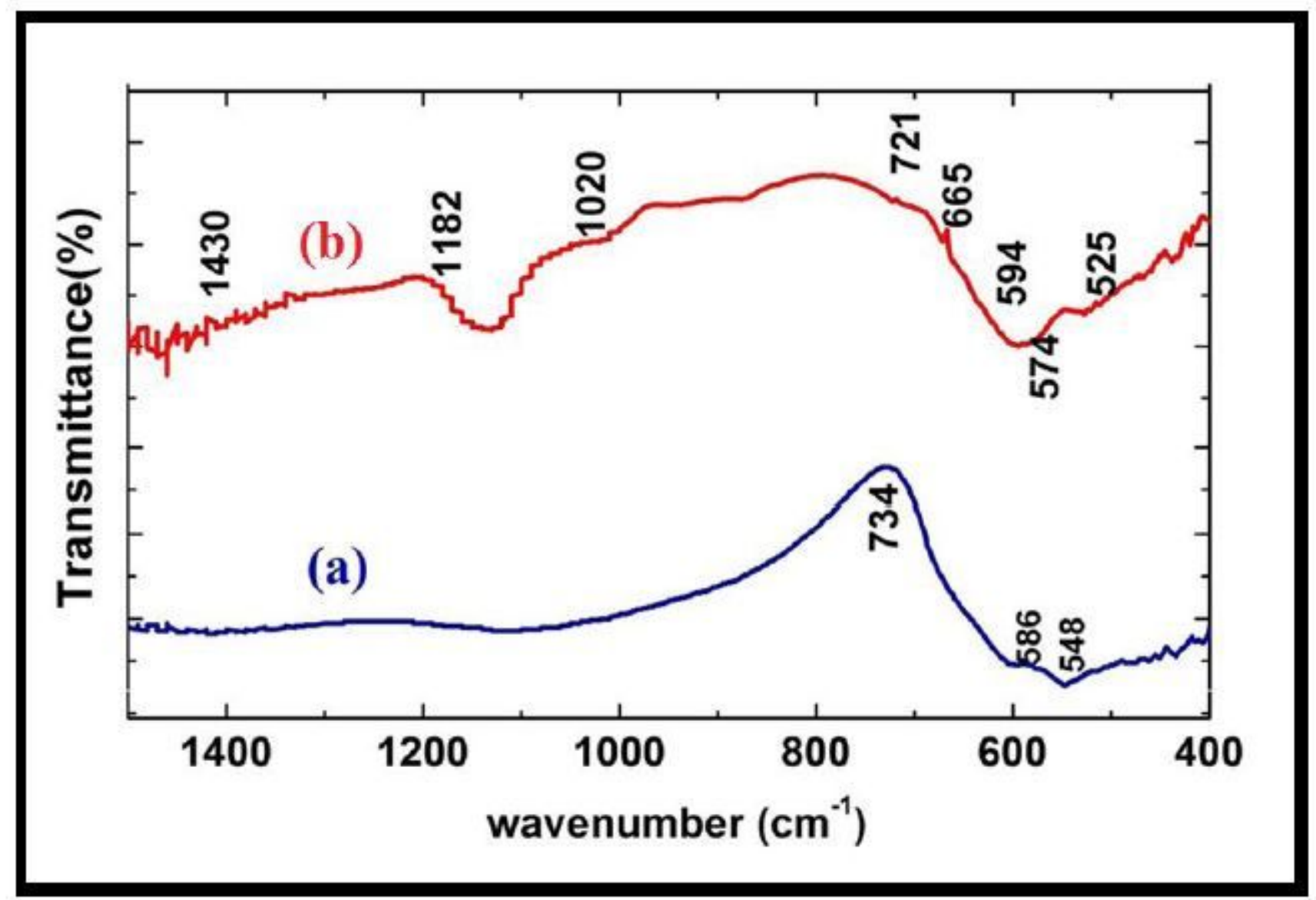

Figure 4

FTIR spectrum of (a) pristine LiNi0.1Mg0.1Co0.802 and (b) fullerene-MWCNT hybrid draped LiNi0.1Mg0.1Co0.802 nanocomposite 


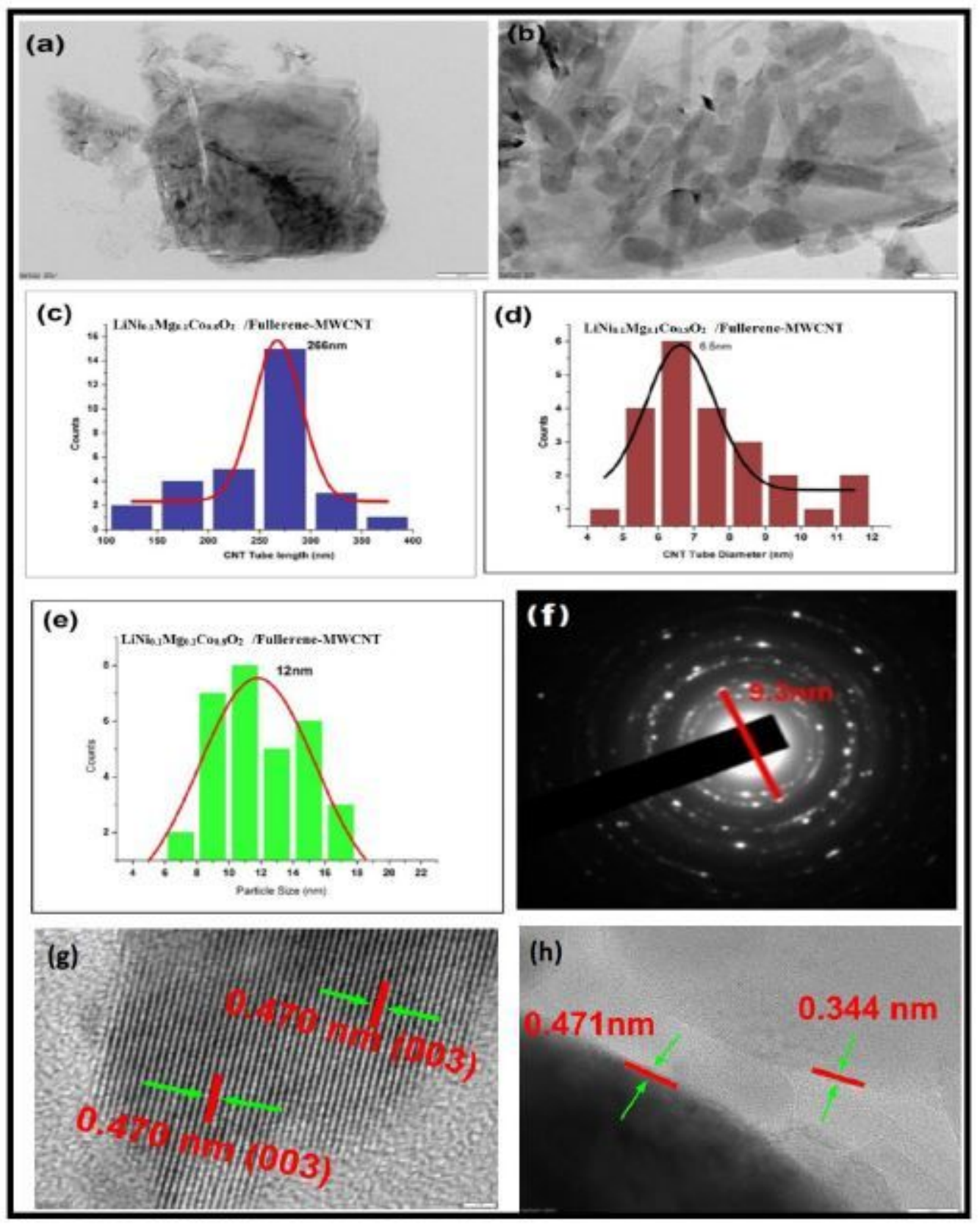

Figure 5

HRTEM images of (a) LiNi0.1Mg0.1Co0.8O2 (b) Fullerene- MWCNT hybrid draped LiNi0.1Mg0.1Co0.8O2 (c)\&(d) Histogram of MWCNT length and diameter distribution in fullerene- MWCNT hybrid draped LiNi0.1Mg0.1Co0.802 (e) Histogram of the particle size distribution in the composite and (f) SAED of fullerene- MWCNT hybrid draped LiNi0.1Mg0.1Co0.802 (g) and (h) Lattice fringes of LiNi0.1Mg0.1Co0.802 and fullerene- MWCNT hybrid draped LiNi0.1Mg0.1Co0.8O2 


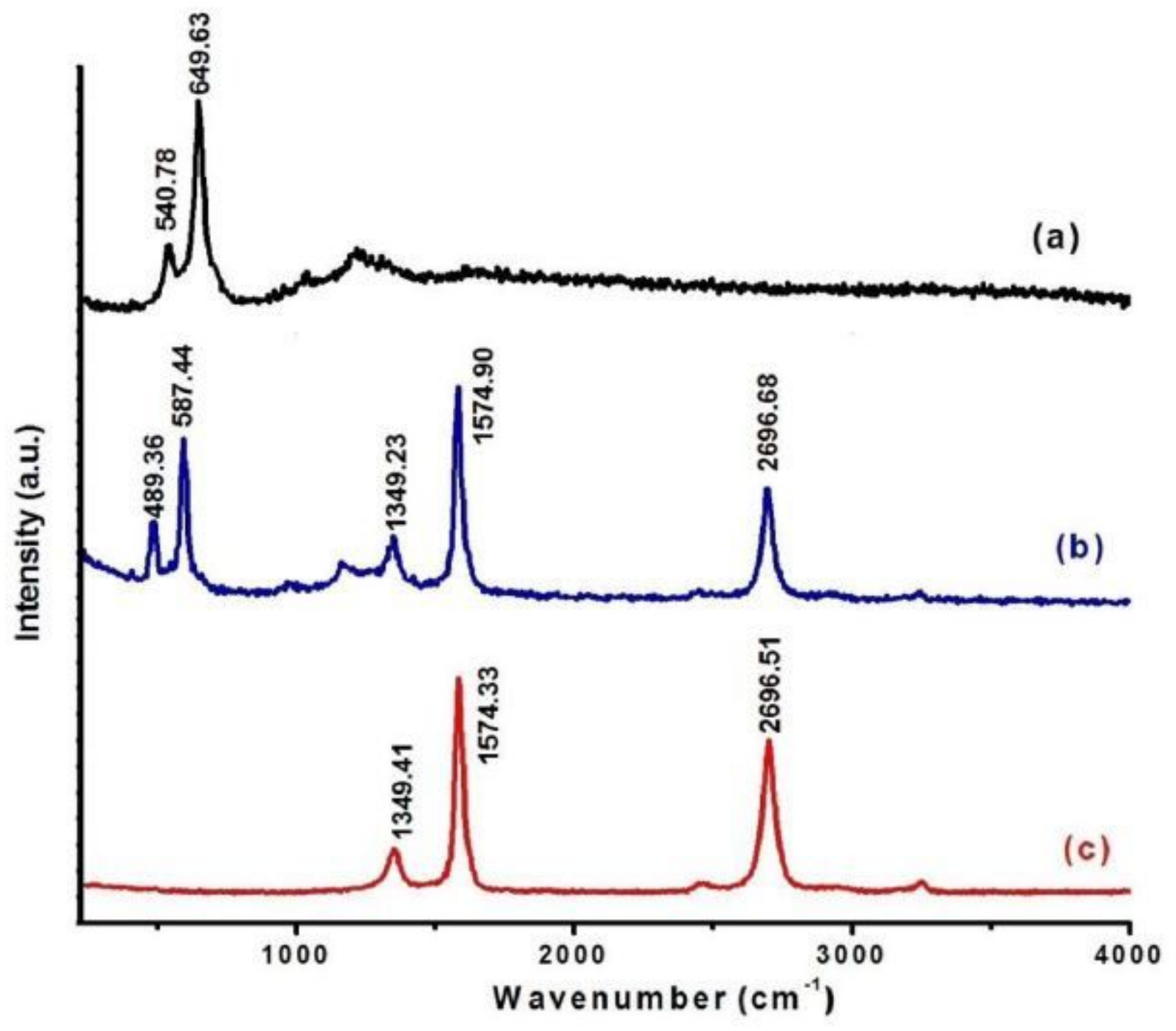

Figure 6

Raman spectrum of (a) pristine LiNi0.1Mg0.1Co0.802,(b) fullerene- MWCNT hybrid draped LiNi0.1Mg0.1Co0.8O2, and (c) fullerene-MWCNT hybrid matrices 


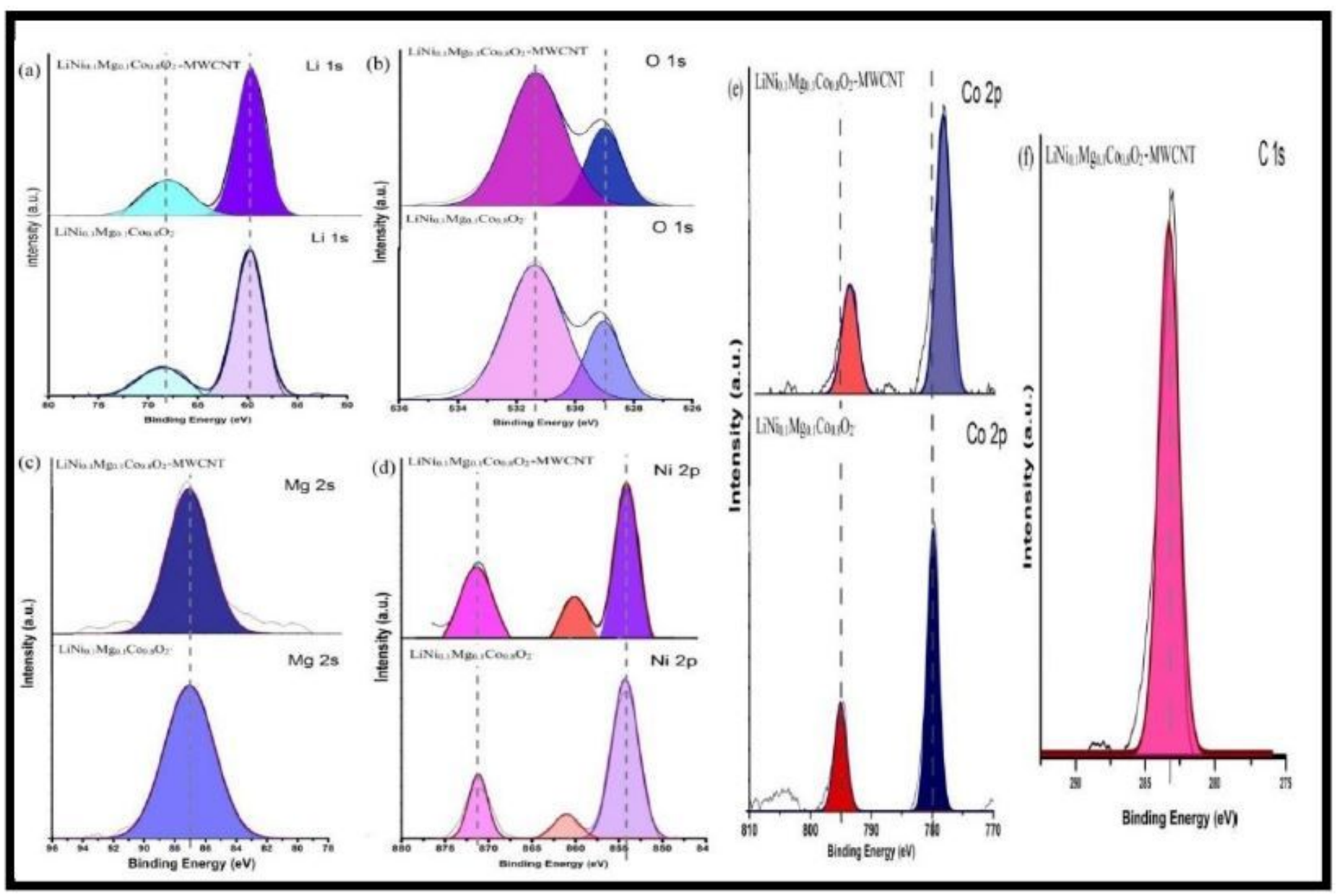

Figure 7

XPS spectra (a) Li 1s (b) 0 1s (c) Mg 2s (d) Ni 2p (e) Co 2p (f) C 1s of LiNi0.1Mg0.1Co0.802 and fullerene- MWCNT hybrid draped LiNi0.1Mg0.1Co0.802
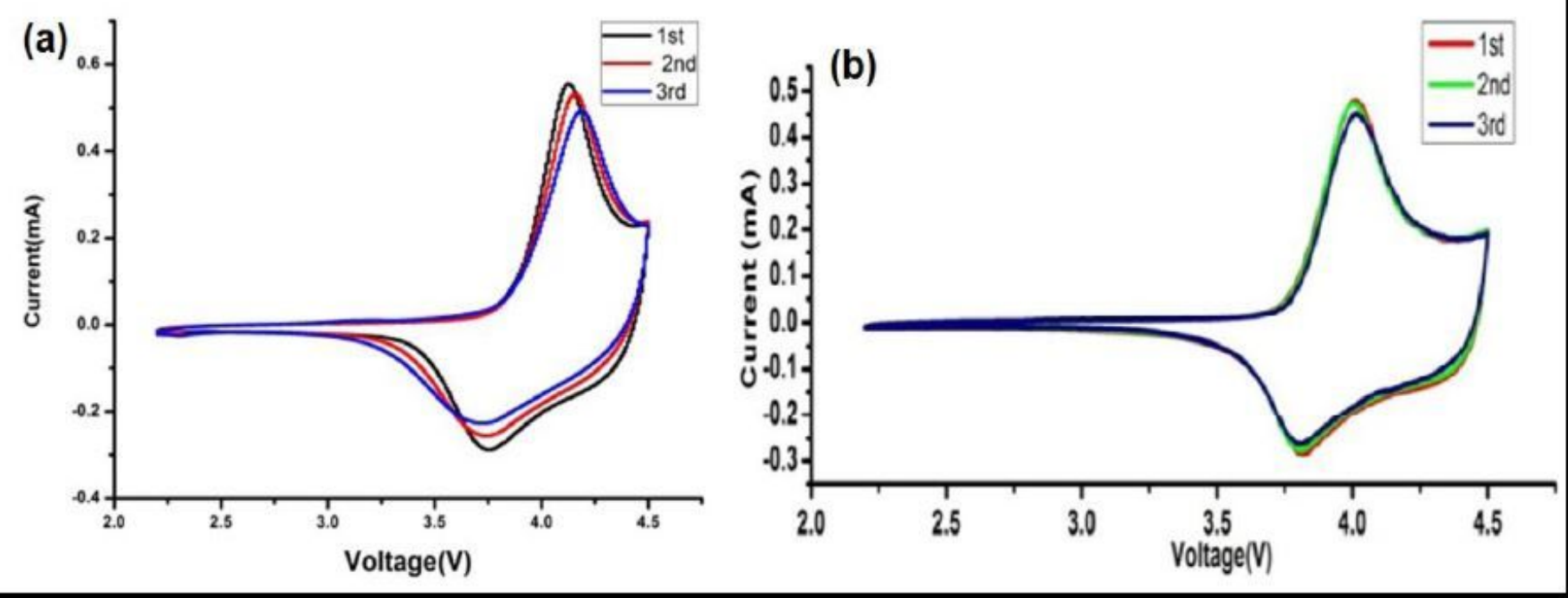

Figure 8 
Cyclic Voltammograms of (a) Li/LiNi0.1Mg0.1Co0.8O2 and (b) Li/LiNi0.1Mg0.1Co0.8O2 + fullereneMWCNT composite cells containing 1M LiPF6 in EC:DEC;1:1(v/v).

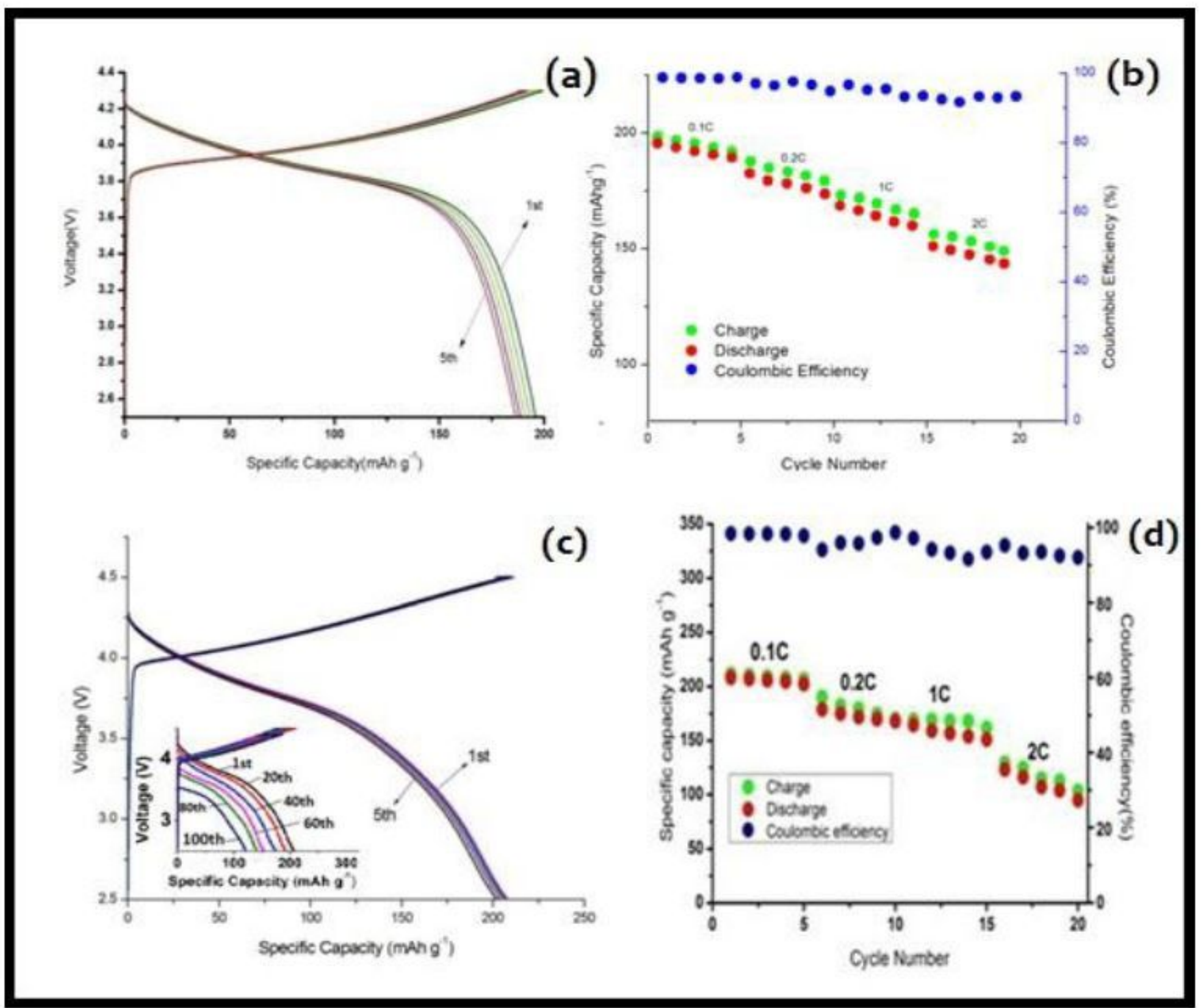

\section{Figure 9}

(a) Cycling profile of Li / LiNi0.1Mg0.1Co0.802 cell containing 1M LiPF6 in EC:DEC;1:1(v/v) at 0.1C(b)

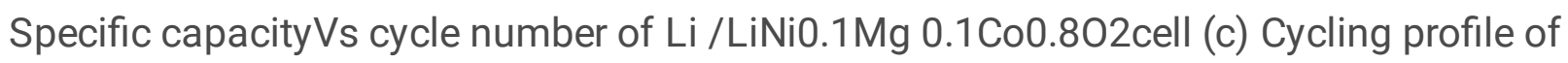
LiNi0.1Mg0.1Co0.802 / fullerene-MWCNTcell containing 1M LiPF6 in EC:DEC;1:1(v/v) at 0.1C at 0.1C, Inset is the 20th, 40th, 60th, 80th, and 100th cycling profile and (d) Specific capacity Vs cycle number of $\mathrm{Li} / \mathrm{LiNi0} .1 \mathrm{Mg} 0.1 \mathrm{Co} 0.802$ + fullerene- MWCNT cell 


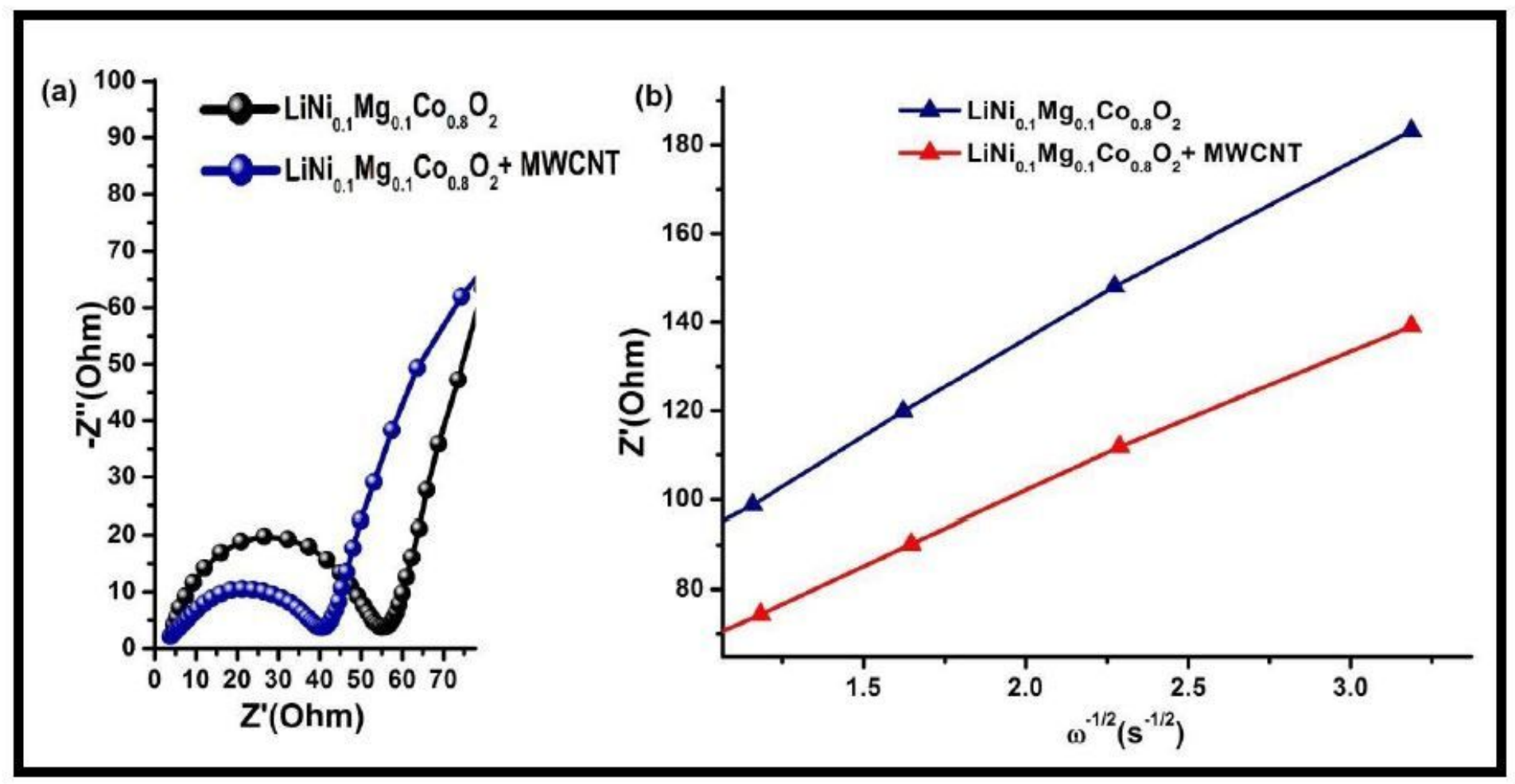

Figure 10

(a) Nyquist plots of LiNi0.1Mg0.1Co0.802 and LiNi0.1Mg0.1Co0.802 / fullerene- MWCNT cell and (b) Plot between $Z^{\prime}$ and $\omega-1 / 2$ for LiNi0.1Mg0.1Co0.802 and LiNi0.1Mg0.1Co0.802 / fullerene-MWCNT cell 